\title{
Occurrence and bacterial cycling of dissolved nitrogen in the Gulf of Riga, the Baltic Sea
}

\author{
Niels O. G. Jørgensen ${ }^{1, *}$, Lars J. Tranvik ${ }^{2, * *}$, Gry Mine Berg ${ }^{3, * * *}$ \\ ${ }^{1}$ Department of Ecology, Royal Veterinary and Agricultural University, Thorvaldsensvej 40, 1871 Frederiksberg C, Denmark \\ ${ }^{2}$ Department of Ecology, Limnology, Lund University, 22362 Lund, Sweden \\ ${ }^{3}$ Horn Point Laboratory, University of Maryland, Center for Environmental Science, Cambridge, Maryland 21613, USA
}

\begin{abstract}
Occurrence, composition and biolability of total dissolved nitrogen (TDN, including dissolved inorganic and organic N ([DIN and DON]) were examined in May and July 1996 in the northern (Köiguste transect) and southern part (Saulkrasti transect) of the Gulf of Riga. In the Saulkrasti transect, the Daugava River was a major source of TDN as indicated by concentrations of up to $60 \mu \mathrm{M}$ TDN in the river plume, compared to about $20 \mu \mathrm{M}$ TDN in the open gulf. DON made up 80 to $90 \%$ of the TDN, but on May 16 a nitrate-rich river plume lowered the proportion of DON to $65 \%$. Riverine DIN and DON stimulated the biological activity along the transect in May, but apparently not in July. In the Köiguste transect, concentrations of TDN were 0.5-fold lower than at Saulkrasti. In May, input of terrestrial nutrients to the inner part of the transect probably increased the biological production. In both transects, the labile DON fraction, defined as bacterial DON degradation over a week, was estimated at 4 to $29 \%$, with an average of $13 \%$. Dissolved combined amino acids (DCAA) made up 10 to $30 \%$ of the DON. A high DON lability coincided with a large proportion of DCAA, relative to TDN, or a high algal biomass. The L/D ratio of especially dissolved combined glutamic acid appeared to be a potential indicator of DON lability. DCAA, as well as dissolved free amino acids (DFAA), were dominant nutrient sources to the bacteria, on average sustaining $77 \%$ (range 8 to $136 \%$ ) of the bacterial $N$ demand. In addition to amino acids, the bacteria incorporated or released DIN and urea. The effect of solar radiation on DON biolability was tested, but no consistent evidence for a light effect on transformation or bacterial utilization of recalcitrant DON was found. Our results show that there is an active microbial cycling of DON in the gulf, driven in part by input of $N$ from the Daugava River. In summer, availability of assimilable $\mathrm{N}$ appears to limit the microbial activity as indicated by an estimated $\mathrm{C} / \mathrm{N}$ ratio of 43 of labile DOM, as compared to a ratio of 4 in May. The microbial $N$ dynamics in the Gulf of Riga are comparable to low-eutrophic estuaries and do not indicate direct eutrophication effects
\end{abstract}

KEY WORDS: Gulf of Riga Total dissolved nitrogen DON DIN - DON lability - Amino acids L/D ratio - Urea . UV radiation

\section{INTRODUCTION}

Dissolved organic nitrogen (DON) is an important constituent of the carbon and nitrogen pools in natural waters. Although a fraction of DON is probably recalcitrant to biological utilization (Thurman 1985), a vari-

·Corresponding author. E-mail: nogj@kvl.dk

Present addresses:

- Department of Limnology, Evolutionary Biology Centre, Uppsala University, 75236 Uppsala, Sweden

-.. Institut für Meereskunde an der Universität Kiel, Düsternbrooker Weg 20, 24105 Kiel, Germany ety of organic nitrogen compounds have been found degradable by microorganisms (Jørgensen et al. 1993. Seitzinger \& Sanders 1997). Microbial utilization of DON is important to the cycling of nitrogen, since dissolved nitrogen becomes available to higher trophic levels via the microbial loop food chain (Azam et al. 1983) or, alternatively, is mineralized to dissolved inorganic nitrogen (DIN), which can be utilized by phytoplankton.

Terrestrial run-off and riverine input can be dominant sources of DON in littoral and coastal waters. In the Baltic Sea, DON constitutes about $50 \%$ of the total 
$\mathrm{N}$ input, but in adjacent rivers the proportion of DON may be higher (Stålnacke 1996). In the Daugava River, a major contributor of water and nutrients to the Gulf of Riga, DON makes up $70 \%$ of the total dissolved nitrogen (TDN), assuming that nitrate is the only DIN component (nitrate was subtracted from TDN to calculate DON; Stålnacke 1996). The amount of DON in Daugava is about $125 \mu \mathrm{M} \mathrm{N}$, as compared to about $20 \mu \mathrm{M} \mathrm{N}$ in the Gulf of Riga (Stånacke 1996, Tamminen \& Seppälä 1999). Dilution of riverine DON cannot explain this 6 -fold lower DON pool in the gulf, as the residence time of gulf water, largely driven by freshwater discharge, is about 3 yr (HELCOM 1996). Rather, the concentration difference indicates a biological degradation of DON in the gulf.

In addition to bacterial utilization of DON, terrestrial and riverine DON can be a supplementary nitrogen source to phytoplankton (Carlsson et al. 1995, 1998, Maestrini et al. 1997). Hence, labile DON may stimulate the biological production via both the microbial loop and enhanced primary production. Accordingly, a large DON input may induce serious eutrophication problems and nuisance blooms of algae. In spite of this, previous research on nitrogen fertilization of marine primary producers has largely focussed on inorganic nitrogen species (Granéli et al. 1986, 1990). The risk of eutrophication effects from DON may be especially significant in the Baltic Sea due to the high input of organic matter from the surrounding countries (Stålnacke 1996).

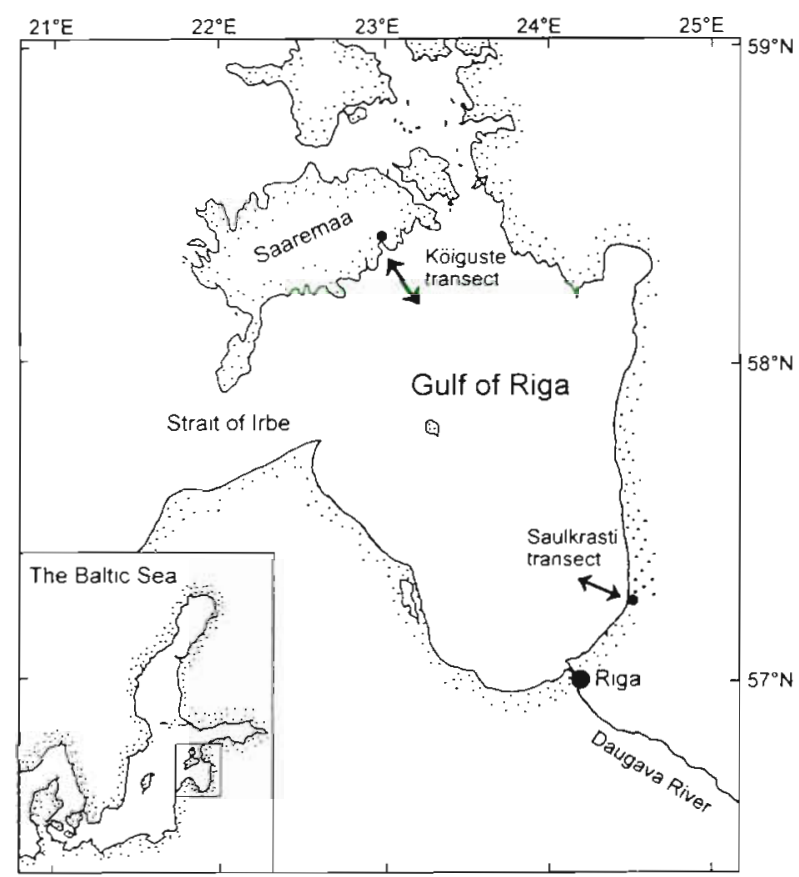

Fig. 1. A map of the Gulf of Riga and the 2 transects studied
Knowledge of sources and sinks of DON in most natural ecosystems, including the Gulf of Riga, is limited. As part of a study on nutrient cycling in the Gulf of Riga, we have attempted to give a preliminary, but yet detailed characterization of occurrence and microbial transformation of DON in the gulf. The studies comprised bacterial utilization of total DON, selected DON components (dissolved free and combined amino acids, DFAA and DCAA, and urea), and DIN (ammonium and nitrate) from selected stations in May and July 1996. Bacterial utilization of DIN was included, as heterotrophic bacteria frequently use DIN as a supplementary nitrogen source (Kirchman et al. 1990, Jørgensen et al. 1993). In order to estimate production and consumption of DON, we also examined occurrence of $\mathrm{D}$ and $\mathrm{L}$ amino acid enantiomers in the DCAA fraction. DCAA in recalcitrant dissolved organic matter (DOM) typically has a L/D ratio of 3 to 4 (Lee \& Bada 1977 . McCarthy et al. 1998), but when eukaryotic organisms, such as algae, release amino acids (exclusively $L$ enantiomers) this ratio may increase up to 8 . Thus, the L/D ratio of amino acids can be used as an indicator of production of new DOM.

Solar light has been shown to transform DOM and increase its availability to microorganisms (Lindell et al. 1995, Jørgensen et al. 1998). This potential effect on the microbial cycling of DOM in the Gulf of Riga was tested in laboratory cultures.

Our results demonstrate that concentration and lability of DON typically decreased with distance from shore in the northern part of the gulf, while a more complex pattern was observed in the southern part due to a distinct nutrient contribution from the Daugava River. The microbial $\mathrm{N}$ dynamics were comparable to low-eutrophic estuaries (Jørgensen et al. 1994, Kroer et al. 1994) and do not indicate direct eutrophication effects in the Gulf of Riga.

\section{MATERIALS AND METHODS}

Sampling. Water samples for analysis of organic and inorganic nutrients and microbial studies (bacterial DFAA uptake and bioassay experiments) were collected in mid-May and late July 1996 in the Gulf of Riga, at stations sampled by the other groups in the Gulf of Riga littoral zone project: the Köiguste gradient (transect southeast of the island Saaremaa) and the Saulkrasti gradient (northwestern transect $20 \mathrm{~km}$ north of Riga) (Fig. 1). All water samples were taken $1 \mathrm{~m}$ below the surface at water depths of $2.5 \mathrm{~m}(\operatorname{Stn} 1), 5 \mathrm{~m}$ (Stn 2, only Saulkrasti gradient), $10 \mathrm{~m}$ (Stn 3) and $20 \mathrm{~m}$ (Stn 4). Distance from the shore to the stations was 0.2 , 4.5 and $13 \mathrm{~km}$ (Köiguste gradient), and 0.1, 0.3, 1.5 and $5.3 \mathrm{~km}$ (Saulkrasti gradient). Additional samples for 
nutrient analysis only were collected in Niskin bottles at depth intervals of 5 to $10 \mathrm{~m}$, at $20 \mathrm{~m}$ (Köiguste transect) and $30 \mathrm{~m}$ water depth (Saulkrasti transect) in 1996 during routine cruises by the Department of Marine Ecology, University of Latvia. All water samples were filtered immediately after sampling at maximum $15 \mathrm{kPa}$ vacuum through $0.2 \mu \mathrm{m}$ Polycap filter capsules (including a glass-fibre prefilter; Whatman International, Maidstone, UK) into acid-washed bottles (Nalge Nunc International, Rochester, USA), and stored frozen until analysis. Salinity in the collected samples ranged from 4.0 to $5.5 \mathrm{ppt}$.

Analysis of TDN. Dissolved nitrogen was determined as TDN, including both DIN and DON, on a Dohrman DN 1900 analyser (Tekmar-Dohrmann, Cincinnati, USA) or an Antek 7000 Nitrogen analyser (Antek Instruments, Inc., Houston, USA). Ammonium, nitrate and urea were measured on an AlpKem FlowSolution IV autoanalyser (OI Analytical, College Station, USA) using standard methods, except for urea which was measured according to Price \& Harrison (1987). Urea was not included in the DON fraction. Although chemically urea is a DON component, it serves as an inorganic $N$ source to both bacteria and algae, and it does not provide energy for the growth of heterotrophic organisms

DFAA and DCAA were quantified as fluorescent o-phthaldialdehyde derivatives by HPLC according to Lindroth \& Mopper (1979) and Jørgensen et al. (1993). DCAA were hydrolysed to individual DFAA by a microwave-assisted vapour phase technique (Jørgensen \& Jensen 1997). For determination of $D$ - and L-isomers of the DCAA, hydrolysed water samples were derivatised and analysed by HPLC according to Nimura \& Kinoshita (1986) and Mopper \& Furton (1991)

Bacterial in situ DFAA uptake. Bacterial assimilation of DFAA was determined from net radiotracer incorporation and actual concentrations of the free amino acids. Triplicate $5 \mathrm{ml}$ water samples and a killed control (containing $2 \%$ formaldehyde) received $10 \mathrm{nCi}$ $(367 \mathrm{~Bq})$ of $4\left[{ }^{14} \mathrm{C}\right]$ amino acids at equimolar concentrations (glutamic acid, serine, glycine and alanine). The added tracers did not exceed $1 \mathrm{nM}$ in concentration, corresponding to a maximum of $1.5 \%$ of their natural concentrations. The incubations were terminated after 30 min by addition of formaldehyde, followed by filtration through $0.2 \mu \mathrm{m}$ membrane filters at maximum $25 \mathrm{kPa}$ vacuum, rinsing with $0.2 \mu \mathrm{m}$ filtered water and counting of the radioactivity on the filters by liquid scintillation.

Bacterial growth capacity. Experiments on potential bacterial growth capacity of DOM in the Gulf of Riga water were performed in the laboratory, using water from all stations sampled. At each station, 5 l of water was filtered immediately after sampling through the
$0.2 \mu \mathrm{m}$ membrane filter capsules as above, and acidified to $\mathrm{pH} 1$ by addition of $\mathrm{HCl}$. In addition, a sample (250 mi) of untreated, original water was retrieved from each station. The samples were stored for approximately $1 \mathrm{wk}$ at 2 to $5^{\circ} \mathrm{C}$ until the start of the experiments

Bacterial cultures from the various stations were set up to assess the ability of heterotrophic bacteria to grow on the organic substrates in the water. The filtered, acidified water samples were restored to a $\mathrm{pH}$ of 8.1 by titration with $\mathrm{NaOH}$. Triplicate cultures were arranged by combining the pH-restored, $0.2 \mu \mathrm{m}$ filtered water with a bacterial inoculum (untreated water filtered through $0.7 \mu \mathrm{m}$ Whatman GF/F filters at 5 to $10 \mathrm{kPa}$ vacuum) from the corresponding station at a 9:1 volume ratio. The cultures were incubated in glass bottles in the dark at $15^{\circ} \mathrm{C}$ in an incubator, and sampled daily for measurements of bacterial growth (increase in cell numbers) for 7 (July cruises) or $8 \mathrm{~d}$ (May cruises). Five $\mathrm{ml}$ samples were preserved with $0.2 \mu \mathrm{m}$. filtered, buffered formaldehyde ( $2 \%$ final conc.) and stored at $4^{\circ} \mathrm{C}$ until staining with DAPI (Porter \& Feig 1980). Bacterial cell numbers and volumes were determined by epifluorescence microscopy. A minimum of 100 cells was measured from each sample, and the bacterial carbon and nitrogen content was estimated with a conversion of $0.308 \mathrm{pg} \mathrm{C} \mathrm{mm}^{-3}$ (Fry 1988) and a 5:1 carbon to nitrogen mass ratio (Kroer et al. 1994). At the final sampling, bacterial cell volumes were measured with an automated image analysis system, connected to a video camera on the microscope.

Additional samples $(1 \mathrm{ml})$ were transferred to vials and frozen until analysis of bacterial DNA content by the dsDNA-specific fluorochrome PicoGreen (Tranvik 1998).

At beginning and end of the incubations, water samples were filtered through $0.2 \mu \mathrm{m}$ membrane filters at a vacuum of 15 to $20 \mathrm{kPa}$ and stored frozen for later analysis of TDN, DON, DIN, DFAA and DCAA.

Experiments on factors controlling bacterial growth. The abovementioned bioassay procedure was applied to all stations (in triplicate cultures) to assess the bacterial growth potential of DOM in unmodified water. For 4 stations, i.e the inner and outer stations of each of the 2 studied transects, additional, manipulated cultures were set up. The manipulations included addition of phosphate $(1.7 \mu \mathrm{M}$ P) together with (1) glucose (41 $\mu \mathrm{M}$ C), or (2) DIN (equal amounts of $\mathrm{NO}_{3}{ }^{-}$and $\mathrm{NH}_{4}{ }^{+}$to a final amount of $7 \mu \mathrm{MN}$, respectively). These manipulations were done to evaluate if organic carbon or inorganic nitrogen would be potentially limiting for bacterial growth

Before addition of bacterial inocula as described above, half of the glucose-amended replicates and half of the DIN-amended replicates were treated with sim- 
ulated solar UV radiation, and the other half was kept in the dark. The purpose of the UV treatment was to investigate possible positive effects of photochemical transformations of DOM on the ability of bacteria to utilize DOC and DON. In cultures amended with both
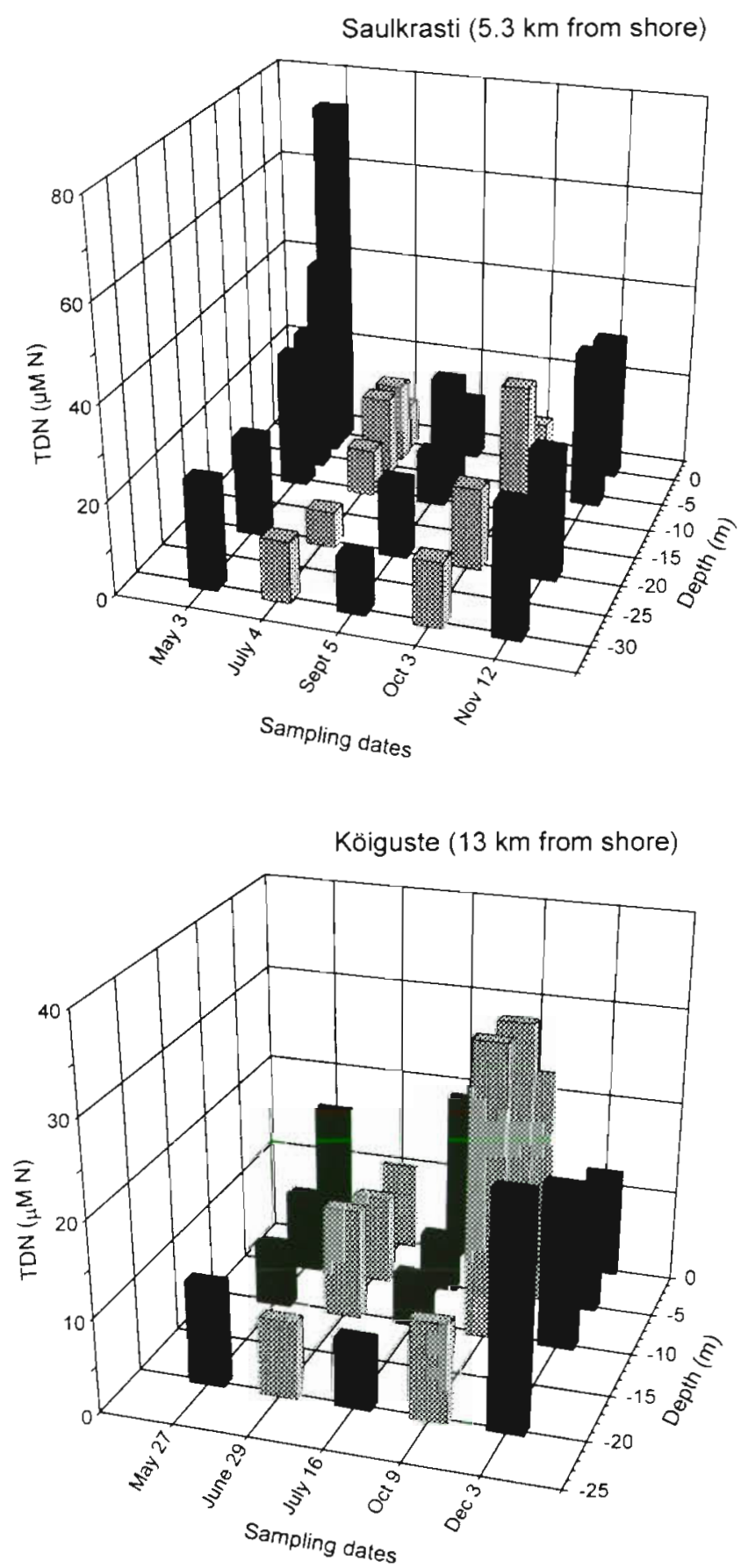

Fig. 2. Depth profiles of total dissolved nitrogen (TDN) at 20 and $30 \mathrm{~m}$ depth in the Köiguste and Saulkrasti transects in 1996. Triplicate analyses of 1 sample from each station were performed. Analytical SDs were 5 to $10 \%$ (not shown) phosphate and DIN, DOC would be the growth-limiting nutrient, and an effect of UV radiation on the availability of DOC would be revealed by comparing UVtreated and non-UV-treated DIN-amended cultures. Similarly, cultures amended with phosphate and glucose would be expected to be limited by nitrogen. A similar comparison of cultures with or without UV treatment would enable detection of an UV effect upon the availability of organic nitrogen as a bacterial substrate. All combinations of UV, dark pre-treatment, and glucose or nitrogen additions were conducted in triplicate.

UV pre-treatment of the $0.2 \mu \mathrm{m}$ filtered water was performed for $12 \mathrm{~h}$ at $20^{\circ} \mathrm{C}$ in wide glass jars covered with a thin, UV-transparent polyethylene film, under a set of fluorescent lamps (Q-Panel UVA-340). Radiation. intensity was measured with a radiometer (IL $1400 \mathrm{~A}_{i}$ Intermational Light, Newburyport, MA, USA). The light intensities were: PAR (photosynthetically available radiation, 400 to $700 \mathrm{~nm}) 6.1 \mathrm{~W} \mathrm{m^{2 }}$, UV-A (320 to $400 \mathrm{~nm}$ ) $20 \mathrm{~W} \mathrm{~m}^{2}$, and UV-B (300 to $320 \mathrm{~nm}$ ) $0.3 \mathrm{~W} \mathrm{~m}^{2}$. The PAR intensity was much lower than normal sunlight, while the UV radiation intensities are comparable to those detected on a sunny day in Lund with the same radiometer $\left(54^{\circ} \mathrm{N}\right.$ i typically $300 \mathrm{~W} \mathrm{~m}{ }^{2}$ of PAR, 35 to $40 \mathrm{~W} \mathrm{m^{2 }}$ of UV-A, and 1.0 to $1.5 \mathrm{~W} \mathrm{~m} \mathrm{~m}^{2}$ of UV-B). Hence, the photochemical effects were probably not stronger than similar effects in surface waters.

\section{RESULTS AND DISCUSSION}

\section{Occurrence of TDN in depth profiles at Saulkrasti and Köiguste}

The Gulf of Riga has a substantial input of nutrientrich freshwater from adjacent rivers, especially the Daugava in the south, which contributes $60 \%$ to the freshwater input to the gulf, while there is an absence of major external inputs to the northern part (Yurkovskis et al. 1993). The nutrient-rich water in the south is transported along the eastern coast, while nutrient-low water from the Baltic Sea enters the gulf via the Strait of Erbe in the north (Berzinsk 1995).

Concentrations of TDN in the Saulkrasti and Köiguste depth profiles in 1996 demonstrated large seasonal changes (Fig. 2). At $30 \mathrm{~m}$ depth at the outermost station in the Saulkrasti transect, TDN typically varied between 10 and $25 \mu \mathrm{M} \mathrm{N}$, but higher concentrations were measured in the upper water column in May (74 $\mu \mathrm{M} \mathrm{N}$ at the surface) and November (about $30 \mu \mathrm{M} \mathrm{N}$ in the entire water column). The annual average TDN concentration was $22.1 \pm 13.9( \pm 1 \mathrm{SD}) \mu \mathrm{M} \mathrm{N}$. The lowest concentrations occurred in July, with a mean of $12.3 \pm 4.2 \mu \mathrm{M}$ N. A depth-integrated normal- 
Table 1. Concentrations of chlorophyll a and phaeopigments along the Köiguste and Saulkrasti transects in depth-integrated samples in 1996 (Møhlenberg \& Conley unpubl. results). Chlorophyll was analysed fluorometrically after filtration (GF/F) and overnight extraction in $96 \%$ ethanol. The concentrations were corrected for content of phaeophytin. Mean values of duplicate samples shown. For phaeopigments, average values of 2 sampling dates in May are given. *May 11

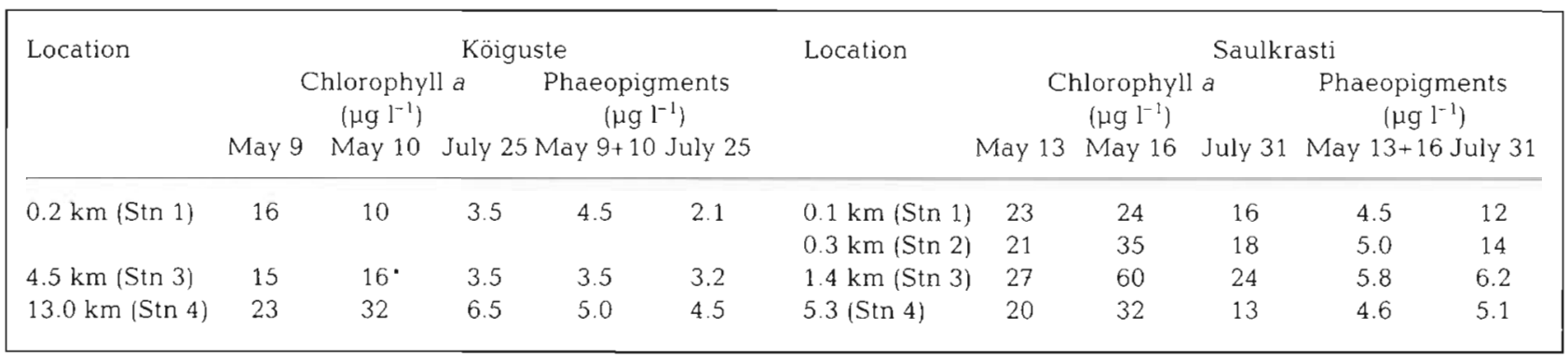

ization of TDN showed that the amount of TDN was 3.0-, 1.3-, 1.5- and 1.8-fold higher in May, September, October and November, respectively, than in July.

At $20 \mathrm{~m}$ depth of the outer part of the Köiguste transect, the average amount of TDN was lower, with an annual mean of $12.3 \pm 4.2 \mu \mathrm{M} \mathrm{N}$, but large variations occurred (Fig. 2). TDN varied from 6 to $7 \mu \mathrm{M} \mathrm{N}$ below $5 \mathrm{~m}$ in July, and to $31 \mu \mathrm{M} \mathrm{N}$ in the upper $10 \mathrm{~m}$ in October. A depth-integrated normalization of TDN, relative to the minimum concentrations in July, demonstrates that the amount of TDN was 1.1-, 1.1-,2.5-and 1.7-fold higher in May, June, October and December, respectively, than in July.

The high TDN concentrations in early May and midNovember in the Saulkrasti profile, relative to the JulyOctober period, probably reflect seasonal variations in both input and consumption of $\mathrm{N}$. The input of $\mathrm{N}$ from Daugava to the gulf is typically lowest in July and August (Stålnacke 1996). In the spring, an intense high algal production occurs in the southern part of the gulf, with a maximum in the Daugava River plume (Tamminen \& Seppälä 1999). In 1996, half of the algal production from April to August in the southern part of the gulf was measured in April (Baloda 1999). During the present study, the algal biomass increased from the shore to the $1.4 \mathrm{~km}$ station on May 16 (Table 1), indicating a previously increasing $\mathrm{N}$ uptake along the Saulkrasti transect, although not at the outermost station.

At Köiguste in the north, no major freshwater pointsources exist, and $\mathrm{N}$ concentrations lower than in the Saulkrasti depth profile generally occurred. Instead terrestrial run-off, local mineralization and, depending on hydrographical conditions, import of $\mathrm{N}$ from Daugava and other rivers may have contributed $\mathrm{N}$ to the Köiguste waters. The lower availability of $\mathrm{N}$ was mirrored by a smaller algal biomass in spring and summer along the transect, relative to the Saulkrasti transect, except at the outer stations where the algal biomass was similar in May (Table 1).
Total (dissolved and particulate) $\mathrm{N}$ has previously been measured for short periods in 1993 through 1995 along transects from the mouth of Daugava to the Strait of Irbe (Tamminen \& Seppälä 1999). Total N pools from these studies agree well with our TDN data, ranging from $14 \mu \mathrm{M} \mathrm{N}$ (middle of Gulf in June and July) to $44 \mu \mathrm{M} N$ (Daugava in April). Tamminen \& Seppälä (1999) also found increased amounts of total $N$ (mainly DON) at depths $\geq 20 \mathrm{~m}$ as we observed in May (Köiguste) and July (Saulkrasti). These $\mathrm{N}$ pools probably originate from mineralisation of organic matter, e.g. settled algae. A high algal biomass (chlorophyll a [chl a] content) was registered at $30 \mathrm{~m}$ depth by Tamminen \& Seppälä (1999) and Baloda (1999).

\section{Occurrence of dissolved nitrogen compounds at Saulkrasti and Köiguste}

Seasonal changes of dissolved $N$ compounds in the Saulkrasti depth profile

Variations of TDN, DON, DCAA, DFAA, $\mathrm{NH}_{4}{ }^{+}$, $\mathrm{NO}_{3}{ }^{-}$and urea, as exemplified by ambient pools at the surface (2.5 $\mathrm{m}$ depth) and above the bottom (30 $\mathrm{m}$ depth), were observed from May to November (Fig. 3). Concentrations of TDN resembled those shown in Fig. 2, except that the maximum TDN pool was only $42 \mu \mathrm{M} N(74 \mu \mathrm{M} N$ was measured earlier in May). The concentration of DON was highest in May and November (maximum of $29 \mu \mathrm{M} \mathrm{N}$ ), while minimum amounts of about $10 \mu \mathrm{M} \mathrm{N}$ were measured in June $(2.5 \mathrm{~m}$ ) and September (both depths). Seasonal concentration changes of TDN and DON were largely similar.

The seasonal variation of DCAA at 2.5 and $30 \mathrm{~m}$ had a comparable trend, but a higher concentration occurred at $2.5 \mathrm{~m}$ in early May. Maximum DCAA concentrations occurred in summer (at $2.5 \mathrm{~m}$ in July and at $30 \mathrm{~m}$ in August) and in November, while minimum 
concentrations were measured in September (Fig. 3) Changes of DCAA and DON had a similar, although statistically weak, trend $(p<0.1$; Spearman rank correlation) at $2.5 \mathrm{~m}$, but not at $30 \mathrm{~m}$. On average, DCAA made up $23 \%$ (range 13 to $37 \%$ ) and $27 \%$ (range 15 to $56 \%$ ) of the DON pool at 2.5 and $30 \mathrm{~m}$ depth, respectively. DFAA fluctuated between 0.1 and $0.3 \mu \mathrm{M} \mathrm{N}$, except for a peak of $0.9 \mu \mathrm{M} \mathrm{N}$ in mid-May.
$2.5 \mathrm{~m}$ Depth
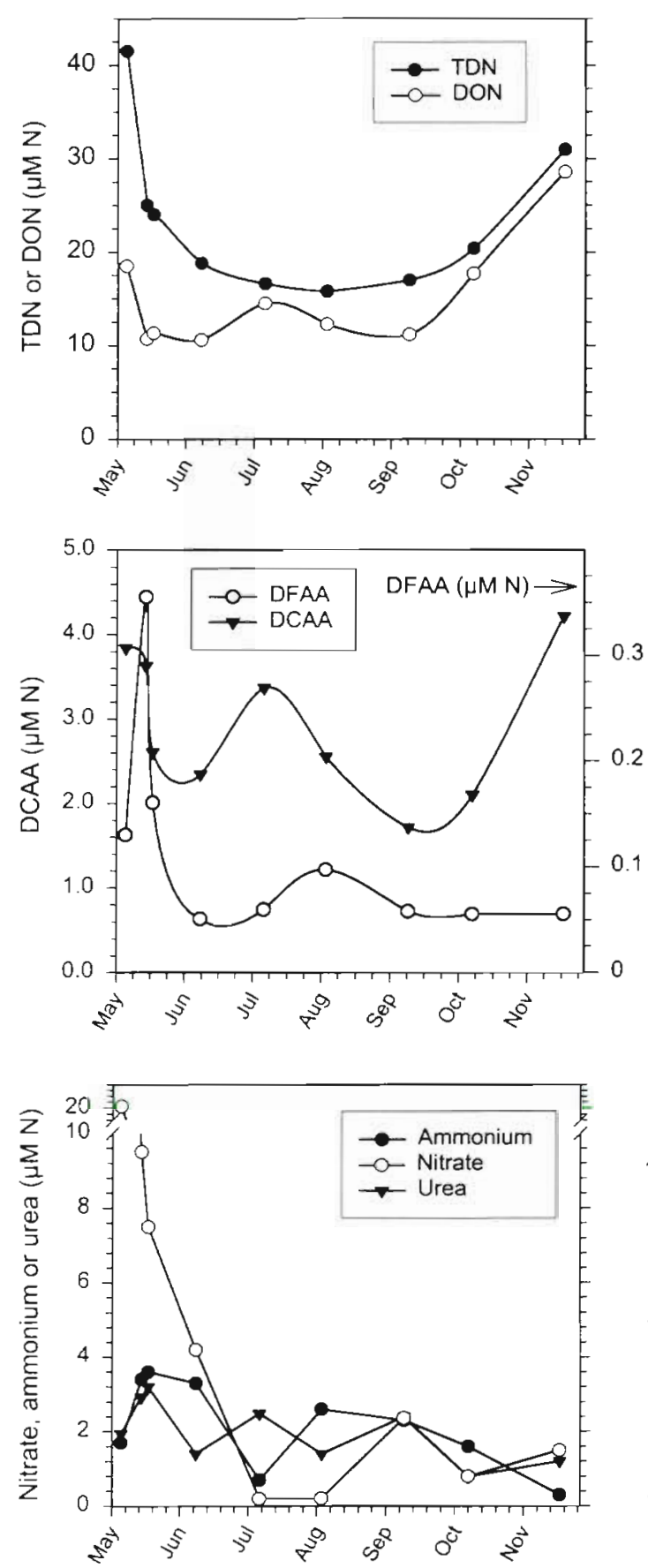

$30 \mathrm{~m}$ Depth
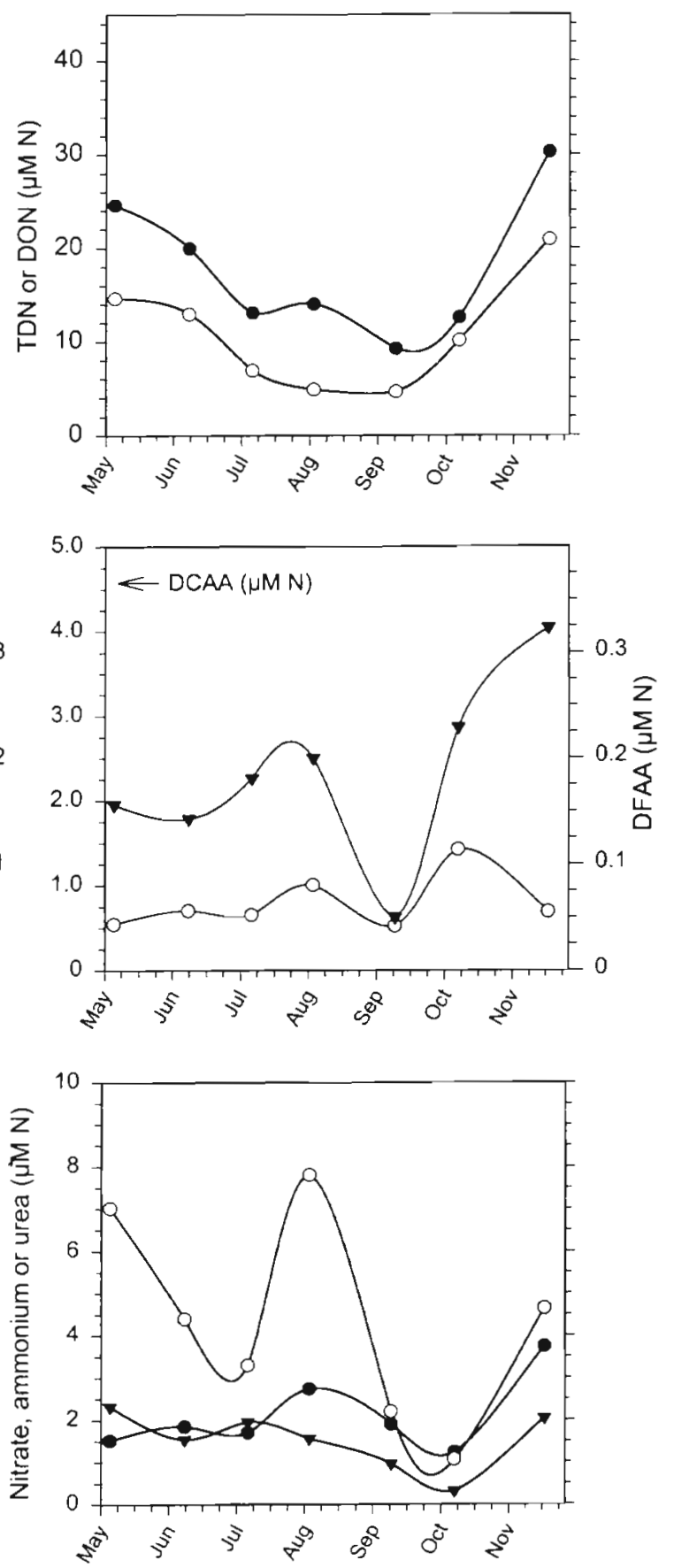

Fig. 3. Seasonal changes of total dissolved nitrogen (TDN), dissolved organic nitrogen (DON), dissolved free and combined amino acids (DFAA and DCAA), nitrate, ammonium and urea at 2.5 and $30 \mathrm{~m}$ depth in the $30 \mathrm{~m}$ depth profile at the Saulkrasti transect (as in Fig. 2) in 1996. Means of triplicate analysis shown. Typical SDs were 5 to $8 \%$ (not shown) 
From June to October, concentration changes of DFAA and DCAA were rather similar, but at $2.5 \mathrm{~m}$ the DFAA maximum occurred 1 mo after the DCAA peak. DFAA made up $2.5 \%$ (range 0.5 to $9.1 \%$ ) and $2.1 \%$ $(0.7$ to $4.5 \%)$ of the DON pool at 2.5 and $30 \mathrm{~m}$, respectively.

Nitrate was the most dynamic DIN compound, with seasonal variations from 0.05 to $20.3 \mu \mathrm{M}$ (Fig. 3). The $\mathrm{NO}_{3}{ }^{-}$peak in May made up $49 \%$ of the TDN pool. $\mathrm{NO}_{3}{ }^{-}$was depleted in the surface in summer, but fluctuated between 1 and $2.5 \mu \mathrm{M}$ in autumn. At $30 \mathrm{~m}$ depth, $\mathrm{NO}_{3}{ }^{-}$varied from 1 to $8 \mu \mathrm{M}$ with a peak in July. $\mathrm{NH}_{4}{ }^{+}$ranged from $0.5 \mu \mathrm{M}$ (surface in summer and autumn) to $3.9 \mu \mathrm{M}$ (surface in spring and bottom in autumn). From July to November, $\mathrm{NH}_{4}^{+}$and $\mathrm{NO}_{3}{ }^{-}$ co-varied and both increased. Urea made up 0.4 to $3.2 \mu \mathrm{M} \mathrm{N}$ (average of $1.8 \mu \mathrm{M} \mathrm{N}$ ) at the 2 depths. No trends between changes in urea and other $\mathrm{N}$ compounds were found at $2.5 \mathrm{~m}$, but at $30 \mathrm{~m}$ urea and $\mathrm{NH}_{4}{ }^{+}$ had opposite trends from May to August and co-varied from August to November.

Changes of dissolved $\mathrm{N}$ compounds along the Köiguste transect in May and July

On May 9 the TDN concentration declined from $29 \mu \mathrm{M}$ $\mathrm{N}$ at the shallow $0.2 \mathrm{~km}$ station, to about $20 \mu \mathrm{M} \mathrm{N}$ at the deeper 4.5 and $13 \mathrm{~km}$ stations (Fig, 4). However, the following day, when strong winds prevailed (D. Conley pers. comm.), similar concentrations were found at 0.2 and $13 \mathrm{~km}$ (no samples were taken at the $4.5 \mathrm{~km}$ station on that day). In July, TDN increased from $18 \mu \mathrm{M} N$ at 0.2 and $4.5 \mathrm{~km}$ to $25 \mu \mathrm{M} \mathrm{N}$ at the outer $13 \mathrm{~km}$ station. DON typically co-varied with TDN and ranged from 15 to $29 \mu \mathrm{MN}$, corresponding to $83 \pm 4 \%$ of TDN.

The amount of DCAA was higher at the $0.2 \mathrm{~km}$ station ( 2.9 to $3.5 \mu \mathrm{M} \mathrm{N}$ ) in both May and July than at the deeper stations (1.8 to $2.1 \mu \mathrm{M} \mathrm{N}$ ) (Fig. 4). Relative to DON, the DCAA pool decreased from 0.2 to $13 \mathrm{~km}$ (from 12 to $7 \%$ in May and from 21 to $11 \%$ in July). The concentration of DFAA varied independent of distance from the shore, but the concentrations were higher in May $(0.36 \pm 0.08 \mu \mathrm{MN})$ than in July $(0.11 \pm 0.01 \mu \mathrm{MN})$. Relative to DCAA, the DFAA concentrations comprised from $16 \pm 4 \%$ (May) to only $4 \pm 2 \%$ in July. DIN typically made up about $2 \mu \mathrm{M} \mathrm{N}$ (urea $1.5, \mathrm{NH}_{4}{ }^{+} 0.5$ and $\mathrm{NO}_{3}{ }^{-} 0.1 \mu \mathrm{M} \mathrm{N}$ ), corresponding to $5-10 \%$ of TDN.

Changes of dissolved $N$ compounds along the Saulkrasti transect in May and July

Due to riverine input of $N$, the concentration of TDN along the transect decreased with distance from the shore in May, but in July no direct influence of $\mathrm{N}$ enriched freshwater was obvious (Fig. 4). On May 13, the TDN pool declined from 35 to $21 \mu \mathrm{M} N$ from the inner to the outer station. Three days later a large $N$ input from the Daugava River had increased the TDN pool to $60 \mu \mathrm{M} \mathrm{N}$ at $0.1 \mathrm{~km}$, with a decline to $24 \mu \mathrm{MN}$ at $5.3 \mathrm{~km}$. In July similar TDN pools of about $20 \mu \mathrm{M} \mathrm{N}$ occurred along the transect.

The concentration of DON along the transect decreased with distance from the shore in May, but the amounts were about 1.7 -fold higher on May 16 than May 13 (Fig. 4). The decline in DON (from 23 to $10 \mu \mathrm{M}$ $\mathrm{N}$ on May 13 , and 38 to $17 \mu \mathrm{M} \mathrm{N}$ on May 16 between the inner and outer stations, respectively) may indicate a dilution as well as a biological uptake. In July rather similar DON pools of about $15 \mu \mathrm{M} N$ occurred in the transect. Relative to May, DON constituted a larger proportion of the TDN pool in July, making up an average of $76 \%$

The amount of DCAA was about 2-fold higher during the Daugava freshet on May 16 than on May 13, and changes along the transect differed (Fig. 4). The DCAA pool along the 3 inner stations gradually declined on May 13 but the amounts were similar on May 16. At the outer station, either higher (May 13) or lower concentrations (May 16) occurred. In July the concentrations of DCAA increased from the inner station $(1.6 \mu \mathrm{M} \mathrm{N})$ to the outer stations $(2.4$ to $2.7 \mu \mathrm{M} \mathrm{N})$. DCAA made up from 7 to $31 \%$ of the DON pool, with a mean value of $14.8 \%$.

The DFAA concentration along the transect varied from 0.27 to $0.98 \mu \mathrm{MN}$ in May, but was significantly lower in July (0.07 to $0.10 \mu \mathrm{M} \mathrm{N}$ ) (Fig. 4). The variable DFAA pools did not show any trends along the transect. DFAA as percentage of DCAA varied significantly (6 to $36 \%$, mean of $20 \%$ ) in May, but in July the percentage declined from the shore to the outer station (5.5 to $2.5 \%$ ), suggesting a higher uptake or a lower production of DFAA at the $5.3 \mathrm{~km}$ station.

In May, DIN was dominated by $\mathrm{NO}_{3}^{-}$(up to $20 \mu \mathrm{M}$ on May 16), while $\mathrm{NH}_{4}{ }^{+}$and urea made up ca 0.5 and $2 \mu \mathrm{M} N$, respectively. In July, $<0.2 \mu \mathrm{M} \mathrm{NO}_{3}{ }^{-}$occurred while $\mathrm{NH}_{4}{ }^{+}$and urea were unaltered.

Fluxes of dissolved nitrogen compounds in the Gulf of Riga

The dominant source of DOM in the Gulf of Riga is probably riverine run-off (Babichenko et al. 1999), but planktonic algae as well as a rich abundance of macrophytes in shallow areas (Kukk 1993) undoubtedly also contribute DOM to the water column. In the present study, DCAA made up a major portion of DON, but the abundance of DCAA appeared not to correlate well 
with the biomass of living or dead phytoplankton. Planktonic algae have been shown to produce DCAA (Hellebust 1965, Ittekkot 1982). Laboratory cultures indicate that the highest release of DCAA occurs during the stationary phase and that actively growing algae typically release a minor amount of DCAA (Flynn \& Berry 1999). Another potential source of DCAA in the gulf is bacterial release during degradation of riverine DON, as has been observed in cultures with humic lakewater (Jørgensen et al. 1998). Since

Köiguste

Saulkrasti

May 9 and 10 (cross-hatched)

May 13 or 16 (cross-hatched)
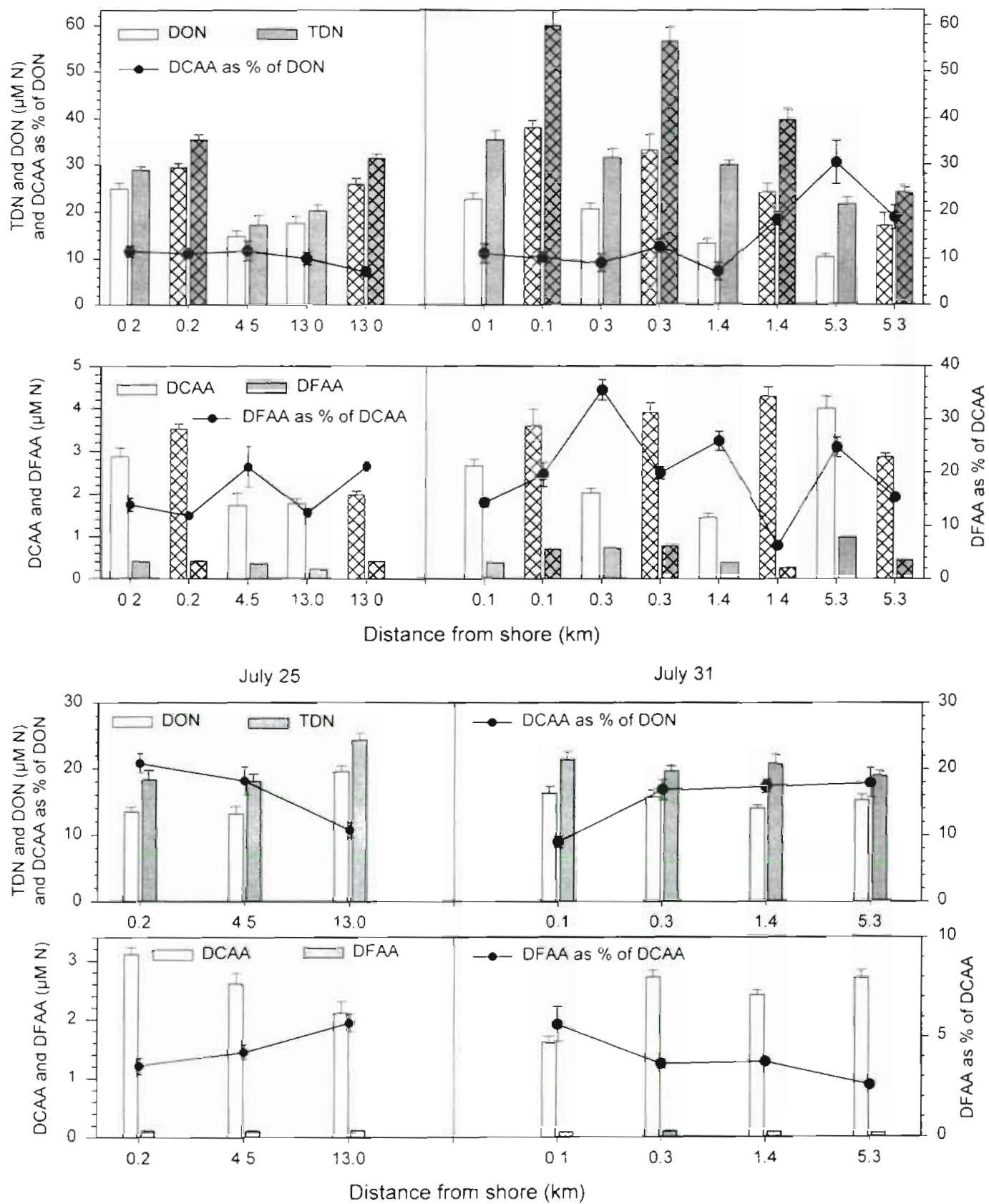

Fig. 4. Concentrations of total dissolved nitrogen (TDN), dissolved organic nitrogen (DON) and dissolved combined and free amino acids (DCAA and DFAA) in the Köiguste and Saulkrasti transects in 1996. On May 10, samples at 0.2 and $13 \mathrm{~km}$ only were collected in the Köiguste transect. The percentage DCAA of DON and DFAA of DCA.A is shown. Means of triplicate analyses $\pm 1 \mathrm{SD}$ are shown 
humic material of terrestrial origin often has a relatively high content of amino acids (Sigleo et al. 1983), it is likely that DCAA were produced during bacterial mineralization of riverine DON.

In the Köiguste transect, the coincidence of maximum chl a concentrations and a minimum DCAA versus DON content at the outer station, $13 \mathrm{~km}$ from the shore, may support a low release of DCAA from growing algae as observed by Flynn \& Berry (1999). The amount of phaeopigments also increased at the outer station (Table 1), but the declining DCAA concentrations do not indicate that dead or inactive algae contributed DCAA to the water. However, it must be remembered that the presence of DCAA reflects a balance between production and degradation, and thus microbial utilization of DCAA (Jørgensen \& Jensen 1997) may have influenced the ambient DCAA pools.

In the Saulkrasti transect, the amount of chl a peaked at the $1.4 \mathrm{~km}$ station in May and July, while the pheopigments were similar (May) or highest at 0.1 and $0.3 \mathrm{~km}$ (July) (Table 1). Thus, the 2 -fold higher proportion of DCAA versus DON at the $1.4 \mathrm{~km}$ (May 16) and $5.3 \mathrm{~km}$ stations (May 13 and 16) only coincided with the chl a maximum at $1.4 \mathrm{~km}$ on May 16. Similarly, no relations between the abundance of DCAA and concentrations of phaeopigments were obvious. Apparently processes other than algal release were important in producing DCAA. Release of DCAA during bacterial degradation of riverine and autochthonous DON, including humic matter, may have been the source of the DCAA as discussed above. The bioassay experiments and the UV treatments both showed that the DON pool contained a relatively large amount of 'unexploited' DCAA, especially at the outer $5.3 \mathrm{~km}$ station in the transect (see Tables $2 \& 4$ ). A portion of these amino acids may have been lost during exoenzymatic bacterial degradation of DON in the water column.

In contrast to the Saulkrasti transect, between 0.1 and $5.3 \mathrm{~km}$, concentrations of DON and DCAA co-varied at $2.5 \mathrm{~m}$ depth in the seasonal Saulkrasti depth profile from May to November (Figs. 3 \& 4). Discharge of $N$ from Daugava was minimal in July (Stålnacke 1996), and thus the increase in DCAA and DON in the summer most likely originated from the cyanobacteria-dominated phytoplankton community (Berg, Glibert \& Jørgensen unpubl data), rather than import of $\mathrm{N}$ from Daugava. The higher DCAA and DIN concentrations at the bottom in August ( 1 mo after the DCAA peak in the surface) suggest that an increased degradation of settled organic matter, e.g. phytoplankton detritus, occurred below the thermocline (at $25 \mathrm{~m}$ depth; Stipa et al. 1999).

Despite the lack of a general coincidence between occurrence of algal biomass and DCAA, the higher and more variable concentrations of DFAA in May than in
July along the 2 transects probably was related to the larger primary production in spring than in summer (Baloda 1999). Release of amino acids by living or dead algae has previously been observed in natural waters (Hammer et al. 1981, Bauerfeind 1985, Capone et al. 1994). In July, the bacterial DFAA assimilation was higher than in May (discussed below) and less phytoplankton production occurred; both processes probably led to the low DFAA pools in July along the gradients.

The measured concentration ranges of DFAA and DCAA, and the relation between the 2 pools in the gulf (DFAA on average equalled 16 to $20 \%$ of DCAA in May, $4 \%$ in July and 8 to $10 \%$ in the depth profiles), fall within previously measured values in estuarine and coastal environments (Coffin 1989, Jorgensen et al. 1993, Keil \& Kirchman 1993). Thus, the significant riverine input of DON to the gulf (Stålnacke 1996) does not lead to an accumulation of DCAA.

The dominance of nitrate as the major DIN component at the bottom in the Saulkrasti depth profile in late summer was probably caused by remineralization of $\mathrm{N}$ from settled material. Due to stratification in the summer, produced $\mathrm{NO}_{3}{ }^{-}$was not mixed into the upper strata, leading to a $\mathrm{NO}_{3}{ }^{-}$depletion in the photic zone. High $\mathrm{NO}_{3}$ pools have previously been found in summer at $30 \mathrm{~m}$, indicating a rather persistent stratification (Maestrini et al. 1997, Tamminen \& Seppälä 1999).

The present concentrations of urea (about $2 \mu \mathrm{MN}$ ) are 2- to 5 -fold below those measured by Maestrini et al. (1997) at the same stations in May and July 1996. The applied analytical techniques may have caused this discrepancy. A decline of urea was expected during the $\mathrm{NO}_{3}{ }^{-}$depletion in July, as urea is a $\mathrm{N}$ source to algae (Kristiansen 1983). Berg, Glibert \& Jørgensen (unpubl. data) actually measured uptake of urea by phytoplankton in the gulf in 1996, and thus the relatively unchanged urea concentrations in our study may indicate that production of urea occurred.

\section{Assimilation of DFAA along the transects}

The assimilation of DFAA generally decreased with distance from the shore in both May and July. In the Köiguste transect on May 9, the assimilation rate de-

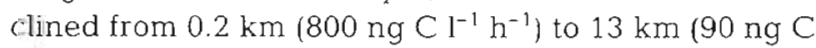
$\mathrm{l}^{-1} \mathrm{~h}^{-1}$ ) (Fig. 5A). On May 10, the rates were lower (140 to $70 \mathrm{ng} \mathrm{C}^{-1} \mathrm{~h}^{-1}$ ), but with a similar trend. In the

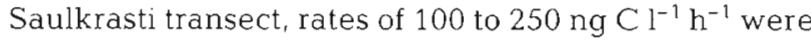
measured on May 13, but during the Daugava freshet on May 16 higher rates were measured at $0.1 \mathrm{~km}$ (1400 ng C $\left.\mathrm{l}^{-1} \mathrm{~h}^{-1}\right)$, and 0.3 and $1.4 \mathrm{~km}\left(400 \mathrm{ng} \mathrm{Cl}^{-1} \mathrm{~h}^{-1}\right)$.

In July the DFAA assimilation in the Köiguste transect varied from $175(0.2 \mathrm{~km})$ to $40 \mathrm{ng} \mathrm{Cl^{-1 }} \mathrm{h}^{-1}(13 \mathrm{~km})$ (Fig. 5B). Higher rates of $480(0.1 \mathrm{~km})$ to $150(5.3 \mathrm{~km})$ 
ng $\mathrm{C}^{-1} \mathrm{~h}^{-1}$ were measured along the Saulkrasti transect on July 31.

The DFAA assimilation (net rates) was related to the net bacterial production, measured by leucine incorporation on selected days in May and July (Zweifel 1999). Bacterial production rates (in units similar to the DFAA assimilation) are shown in Fig. 5A,B. Except for Köiguste in July, the production decreased with distance from shore. The contribution of amino acid $C$ to the bacterial growth was estimated to sustain from about $25 \%$ (Köiguste in July) to $50 \%$ (Köiguste in May and Saulkrasti in July) and about $80 \%$ (Saulkrasti in May) of the net bacterial $C$ demand.

In addition to availability of substrates such as DFAA along the transects, temperature was found to be a major regulating factor of the bacterial production in the gulf (Zweifel 1999). Temperature has previously been found to be a main controlling factor for estuarine bacterial production (Shiah \& Ducklow 1994). The bacterial production was 3 - to 5-fold higher in July than in May, but due to the Iow DFAA pools in summer the contribution of DFAA-C to the bacterial C demand was reduced by about $50 \%$ in July. This means that the bacterial production in the summer may have been regulated by the availability of DFAA. Unfortunately, in some cases the bacterial production was measured the day before or after, instead of on the same day as the DFAA assimilation. This means that the actual sustenance of DFAA-C to the bacterial production may have differed from our estimates.

The DFAA assimilation rates in the Gulf of Riga fall within previously reported values for coastal and estuarine locations (Billen et al. 1980, Coffin 1989). According to Hoch \& Kirchman (1995), DFAA are more important $\mathrm{C}$ and $\mathrm{N}$ sources to bacteria in eutrophic than in oligotrophic conditions. Supporting this, DFAA met most of the bacterial $C$ demand in the rather eutrophic Chesapeake Bay plume (Fuhrman 1990). Applying the Hoch \& Kirchman (1995) observations to the Gulf of Riga, and ignoring the difference in bacterial production in May and July, our data suggest that the Köiguste transect in July was the most nutrient poor, while the Saulkrasti transect in May was the most nutrient rich.

\section{Bacterial growth potentials in the Köiguste and Saulkrasti transects}

Bacterial carrying capacities

Laboratory incubations of bacteria in water from the different stations resulted in typical batch culture
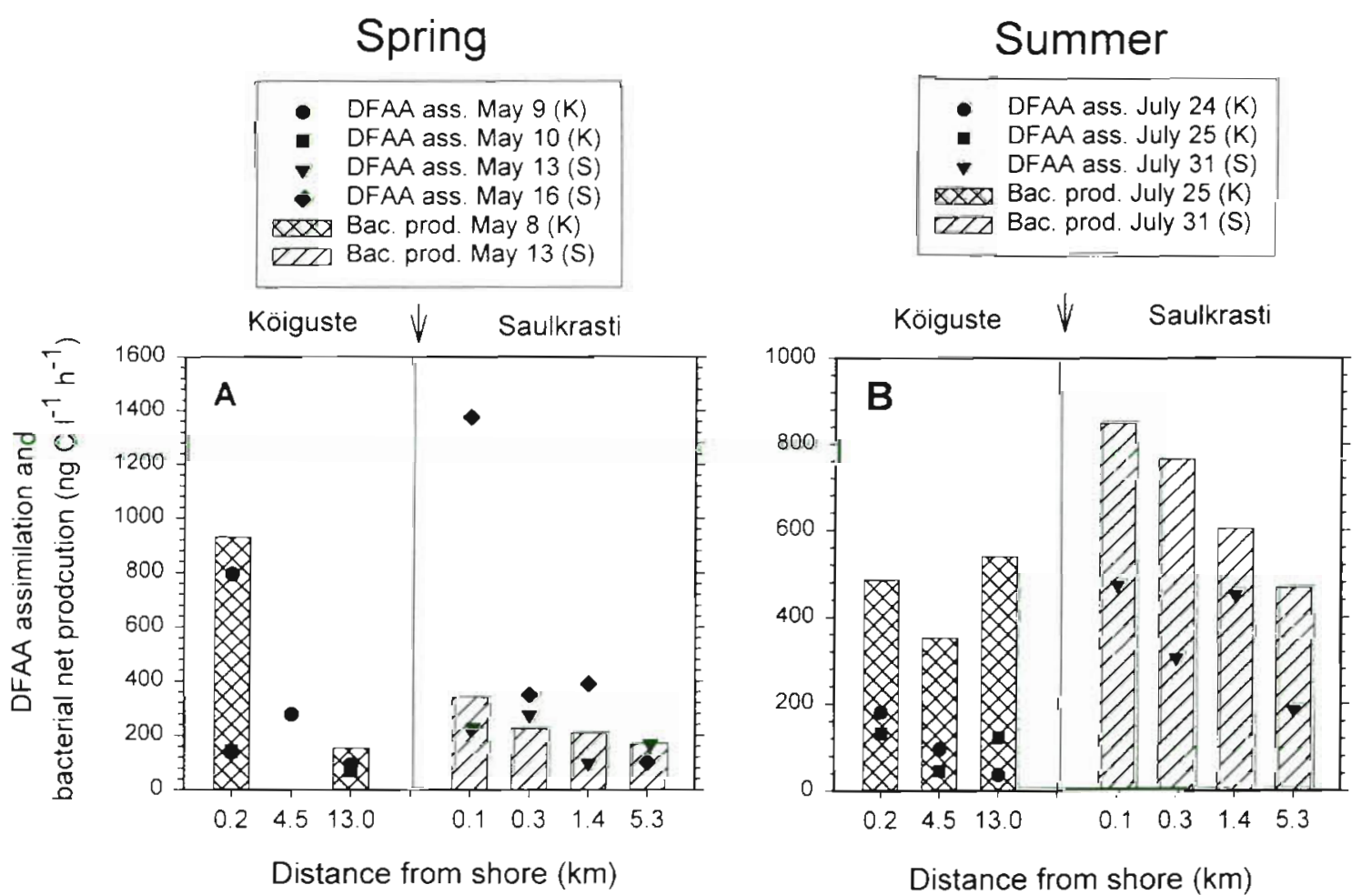

Fig. 5. Net assimilation rates of DFAA (symbols) and bacterial production (bars) measured at in situ conditions in water samples from $1 \mathrm{~m}$ depth in the Köiguste $(\mathrm{K}$ ) and Saulkrasti (S) transects in (A) spring and (B) summer 1996. Means of triplicate analysis shown. SDs were 5 to $12 \%$ (DFAA assimilation) and 10\% (bacterial production). Bacterial production data were kindly provided by U. L. Zweifel 
growth curves, which reached stationary phase within the incubation period. Hence, the incubations can be successfully used to assess bacterial carrying capacity, derived from bacterial biovolumes at the end of incubations.

In the Köiguste transect in May, the inner station had a 3.5 -fold higher carrying capacity than the stations further from shore (Fig. 6). In the Saulkrasti transect, the carrying capacity in May at 0.1 and $5.3 \mathrm{~km}$ was similar to the $0.1 \mathrm{~km}$ Köiguste station, while it was 0.7 -fold lower at 0.3 and $4.1 \mathrm{~km}$. In July there was a weak trend of a decreasing bacterial carrying capacity with distance from the shore at both transects, and the bacterial biomass was about 2 -fold higher in the Saulkrasti than the Koiguste gradient.

A comparison of the bacterial production, measured by leucine incorporation

(Fig. 5), and the biomass accumulation (Fig. 6) demonstrates a similar, declining trend with distance from the shore in Köiguste in May and Saulkrasti in July, while inconsistent results occurred on the other days. However, the 2 methods differ with respect to bacterial substrate consumption. Bacterial production measured by leucine incorporation represents a 30 min snapshot of the growth rates, while the carrying capacity studies illustrate potential consumption of all labile DOM substances.

\section{Bacterial $N$ sources in the carrying capacity studies}

The bacterial nitrogen incorporation in the carrying capacity experiments was determined from an expected bacterial C/N ratio of 5 (Kroer et al. 1994), and related to changes in dissolved nitrogen compounds in the water. The nitrogen compounds included total amino acids (DFAA + DCAA), urea, $\mathrm{NH}_{4}{ }^{+}$and $\mathrm{NO}_{3}{ }^{-}$. In order to estimate the bacterial utilization of DON, the acquired bacterial $\mathrm{N}$ biomass was related to the initial DON concentration in the cultures. The DON uptake was corrected for release of DIN, assuming that produced DIN was mineralized DON, and thus it was added to the DON uptake.

During the incubations, concentrations of DFAA on average decreased by $54 \%$, while DCAA were reduced by about $20 \%$ in 9 cultures, released in 2 cultures, and remained unchanged in 3 cultures (Table 2). Urea, $\mathrm{NH}_{4}{ }^{+}$and $\mathrm{NO}_{3}{ }^{-}$were either assimilated, released or unaltered. Uptake of DFAA and DCAA on average corresponded to $77 \%$ (range 8 to $136 \%$ ) of the bacterial $\mathrm{N}$ biomass accumulation. Minimum and maximum amino acid uptake occurred in July, when amino $\mathrm{N}$ met 8 to $47 \%$ (Saulkrasti) and 115 to $139 \%$ (Köiguste) of the bacterial $\mathrm{N}$ demand.

No simple relations between bacterial uptake of amino acids, $\mathrm{NH}_{4}{ }^{+}, \mathrm{NO}_{3}{ }^{-}$and urea were obvious, except that uptake of $\mathrm{NH}_{4}{ }^{+}$and $\mathrm{NO}_{3}{ }^{-}$only occurred in cultures in which amino $\mathrm{N}$ did not meet all of the bacterial $\mathrm{N}$ demand. Uptake of urea even occurred in cultures with an amino $\mathrm{N}$ uptake exceeding the bacterial $\mathrm{N}$ incorporation, suggesting that urea can be as important as amino $\mathrm{N}$ to bacteria. Urea was also a bacterial release product. In water from the $5.3 \mathrm{~km}$ Saulkrasti station in May, a large amino acid uptake (exceeding the bacterial $\mathrm{N}$ incorporation by $36 \%$ ) was compensated for by a release of both urea and DIN. Obviously release of urea can be used to counterbalance an excess amino acid uptake. Bacterial urea dynamics in natural populations are complex and not well understood. However, recent reports indicate that heterotrophic bacteria are important in cycling of urea in the sea (Cho et al. 1996).

A comparison of net uptake of amino acids, urea, $\mathrm{NH}_{4}{ }^{+}$and $\mathrm{NO}_{3}^{-}$(all based on concentration changes), and the bacterial $\mathrm{N}$ biomass production, demonstrates that these $N$ compounds accounted for $\geq 100 \%$ of bacterial $\mathrm{N}$ demand in 8 of the 14 cultures (Table 2). In the remaining 6 cultures, the bacteria must have utilized other $\mathrm{N}$ compounds in addition to the presently studied substances. A contribution $>100 \%$ suggests that $\mathrm{N}$ compounds not accounted for in our study, e.g. amines, amino sugars and nucleotides, were released by the bacteria. Alternatively, the expected bacterial $\mathrm{C} / \mathrm{N}$ ratio of 5 did not represent the actual bacterial composition. 
Table 2. Bacterial incorporation of nitrogen during the carrying capacity studies. The accumulated bacterial $\mathrm{N}$ biomass was related to concentration changes (indicated by $\triangle$ ) of amino acids (DFAA + DCAA), urea (U), ammonium and nitrate during incubation periods of 7 (July) or 8 (May) days. Only concentration changes statistically different at a $5 \%$ level ( $t$-test) were included. Negative values indicate a release. To estimate the bacterial consumption of DON, the acquired bacterial biomass $N$ was corrected for uptake or release of urea and DIN, and related to the initial DON concentration in the water. Mean values of triplicate samples shown. "Different from $100 \%$ ( $p<0.05$, $t$-test). Note: Accumulated SDs of the individual analysis imply that SDs of the $\mathrm{N}$ balances (the 2 columns to the right) are 10 to $20 \%$. If the amino acid assimilation ( $\triangle A A$ ) exceeded the bacterial $N$ incorporation, all of the DON incorporation was assumed to be due to amino acid assimilation. If assimilation of amino acids, urea and DIN was less than the bacterial biomass $N$ incorporation, the missing bacterial $N$ was assumed to be due to incorporation of unidentified DON. Values within parentheses are \% of the total DON pool

\begin{tabular}{|c|c|c|c|c|c|c|}
\hline & $\begin{array}{l}\text { Biomass } \\
(\mu M N)\end{array}$ & $\begin{array}{c}\triangle \mathrm{AA} \\
(\mu \mathrm{MN})\end{array}$ & $\begin{array}{l}\text { AUrea } \\
(\mu \mathrm{MN})\end{array}$ & $\begin{array}{c}\Delta\left(\mathrm{NH}_{4}{ }^{+}\right. \\
\left.\text {and } \mathrm{NO}_{3}{ }^{-}\right) \\
(\mu \mathrm{MN})\end{array}$ & $\begin{array}{l}\Delta\left(\mathrm{AA}_{+} \mathrm{U}_{+}\right. \\
\text {DIN) vs bac- } \\
\text { terial } \mathrm{N}(\%)\end{array}$ & $\begin{array}{l}\text { DON in- } \\
\text { corporation } \\
(\mu \mathrm{N})\end{array}$ \\
\hline \multicolumn{7}{|l|}{ Spring } \\
\hline \multicolumn{7}{|c|}{ Köiguste, May 11} \\
\hline $0.2 \mathrm{~km}$ & 3.70 & 3.35 & 0.46 & 0.34 & 112 & $3.9(15)$ \\
\hline $4.5 \mathrm{~km}$ & 1.01 & 1.37 & 0 & 0 & $135^{\circ}$ & $1.4(10)$ \\
\hline $13 \mathrm{~km}$ & 0.97 & 0.30 & 0.42 & 0 & $75^{\circ}$ & $0.7(3.6)$ \\
\hline \multicolumn{7}{|c|}{ Saulkrasti, May 16} \\
\hline $0.1 \mathrm{~km}$ & 3.69 & 2.51 & 1.22 & 0 & 101 & $9.7(26)$ \\
\hline $0.3 \mathrm{~km}$ & 2.29 & 2.73 & 0 & 0 & 119 & $8.7(26)$ \\
\hline $1.4 \mathrm{~km}$ & 2.61 & 0.56 & 0 & 2.53 & 118 & $1.4(5.7)$ \\
\hline $5.3 \mathrm{~km}$ & 3.67 & 4.97 & -0.50 & -2.23 & $61^{\circ}$ & $4.9(29)$ \\
\hline \multicolumn{7}{|c|}{ Summer } \\
\hline \multicolumn{7}{|c|}{ Köiguste, July 25} \\
\hline $0.2 \mathrm{~km}$ & 1.41 & 1.96 & 0.20 & 0 & $153^{\circ}$ & $1.9(15)$ \\
\hline $4.5 \mathrm{~km}$ & 1.16 & 1.26 & 0.64 & 0 & $165^{\circ}$ & $1.3(9.6)$ \\
\hline $13 \mathrm{~km}$ & 0.98 & 1.12 & 0.44 & 0 & $159^{\circ}$ & $1.1(5.7)$ \\
\hline \multicolumn{7}{|c|}{ Saulkrasti, July 31} \\
\hline $0.1 \mathrm{~km}$ & 2.44 & 0.19 & -0.34 & 1.48 & $54^{\circ}$ & $1.3(8)$ \\
\hline $0.3 \mathrm{~km}$ & 2.12 & 0.99 & 0 & 0.56 & $73^{\circ}$ & $1.6(10)$ \\
\hline $1.4 \mathrm{~km}$ & 2.12 & 0.43 & 0 & 0 & $20^{\circ}$ & $2.1(15)$ \\
\hline $5.3 \mathrm{~km}$ & 1.45 & 0.48 & 0.24 & 0 & $50^{\circ}$ & $1.3(8.8)$ \\
\hline
\end{tabular}

curred in most of the cultures. If no DIN had been available, a larger portion of the DON pools may have been utilized. The 2-fold higher concentrations and lability of DON along the Saulkrasti than the Köiguste transects in May (on average 3 and $6 \mu \mathrm{M} D O N$ $\mathrm{N}$, and 9.5 and $22 \%$ labile DON at Koiguste and Saulkrasti, respectively) agreed well with the about 2 -fold higher bacterial biomass accumulation at Saulkrasti than at Köiguste (except at the inner Koiguste and Saulkrasti stations when a similar biomass was acquired) (Fig. 6). But in July, when amounts and lability of DON were similar at the 2 transects, the biomass accumulation was still 2 -fold higher at Saulkrasti than at Köiguste (Table 2). The reason for the higher biomass at Saulkrasti in July is not obvious, as the studied $N$ compounds here only met about half of the bacterial $\mathrm{N}$ demand, compared to $>100 \% \mathrm{~N}$ sustenance at Köiguste. The discrepancy suggests that there was a supply of nutrients, including $N$ compounds other than those presently analysed, in the Daugava River plume. The high biomass accumulation at the inner station in May at Köiguste probably indicates a terrestrial- or freshwater-derived input of nutrients at this shallow station, compared to the outer stations.

The estimated DON lability in the gulf was lower than that measured in

\section{Lability of DON}

The calculated bacterial DON consumption allows an estimation of the lability of DON, assuming that all labile DON compounds in the water were assimilated during the incubations. The results indicate that on average $1.3 \%$ (range 3.6 to $29 \%$ ) of the DON was assimilable for 7 or $8 d$ (Table 2). In the Köiguste transect in May and July there was a clear correlation between distance from the shore and a decreasing percent lability (linear regression with a correlation coefficient $\mathrm{r}^{2}=0.94$ ). Interestingly, this trend agrees with that of the DCAA\% of DON (Fig. 4). In the Saulkrasti transect, no trends were obvious; the lowest lability occurred either at the intermediary $1.4 \mathrm{~km}$ station (May) or at the inner $(0.1 \mathrm{~km})$ and outer $(5.3 \mathrm{~km}) \mathrm{sta}-$ tions (July).

The estimated labile DON pools must be considered as minimum values, as additional uptake of DIN oc- the Delaware and Hudson River estuaries, where DON was reduced by 40 to $72 \%$ within 10 to $15 \mathrm{~d}$ in similar bacterial cultures (Seitzinger \& Sanders 1997). The quality of DON in the Gulf of Riga may be lower than in those 2 estuaries, e.g. due to a larger proportion of humic substances and a smaller input of anthropogenic matter in Daugava than in the American rivers.

The $\mathrm{C} / \mathrm{N}$ ratio of labile DOM along the transects can be estimated from the labile DON pools (Table 2) and the amount of labile DOC, determined by an incubation procedure similar to that presently applied (Zweifel 1999). The $\mathrm{C} / \mathrm{N}$ ratio of labile $\mathrm{DOM}\left(\mathrm{DOC}_{\text {labile }}\right.$ $\mathrm{DON}_{\text {labile }}$ ) at the 2 transects was estimated to be 4.0 (range 1.5 to 7.2 ) in May and 43 (range 25 to 55 ) in July. The estimates indicate that labile DON was depleted in summer. Bacterial growth efficiencies (produced biomass $\mathrm{C}$ relative to consumed DOC) were on average $18 \%$ (May) and 6\% (July) (Zweifel 1999). The low growth efficiency in July suggests that, due to a DON 
Table 3. Effect of enrichment with glucose $(+\mathrm{Glu}, 41 \mu \mathrm{MC})$ or DIN (+DIN; $7 \mu \mathrm{M} \mathrm{N}$; equal amounts of $\mathrm{NO}_{3}^{-}$and $\left.\mathrm{NH}_{4}{ }^{+}\right)$in combination with $12 \mathrm{~h}$ UV radiation pre-treatment of water from the transects on bacterial biomass accumulation. Numbers indicate $x$-fold stimulation or inhibition after 7 (July) or $8 \mathrm{~d}$ (May) of incubation, relative to non-manipulated controls. -: no significant change in biomass after treatment ( $t$-test, $p>0.05)$; 'Significant effect of UV radiation, e.g. between + Glu and + Glu and UV $(t$-test, $\mathrm{p}<0.05)$

\begin{tabular}{|c|c|c|c|c|c|c|c|c|}
\hline \multirow{3}{*}{ Addition } & \multicolumn{4}{|c|}{ Köiguste } & \multicolumn{4}{|c|}{ Saulkrasti } \\
\hline & \multicolumn{2}{|c|}{ May 9} & \multicolumn{2}{|c|}{ July 25} & \multicolumn{2}{|c|}{ May 16} & \multicolumn{2}{|c|}{ July 31} \\
\hline & $0.2 \mathrm{~km}$ & $13 \mathrm{~km}$ & $0.2 \mathrm{~km}$ & $13 \mathrm{~km}$ & $0.1 \mathrm{~km}$ & $5.3 \mathrm{~km}$ & $0.1 \mathrm{~km}$ & $5.3 \mathrm{~km}$ \\
\hline+ Glu & - & 2.7 & 1.3 & 1.5 & 5.8 & 1.9 & 1.8 & 1.2 \\
\hline+ DIN & - & 3.7 & 3.5 & 5.3 & - & - & 2.1 & 2.2 \\
\hline +Glu and UV & $1.7^{\circ}$ & $3.5^{\circ}$ & $2.8^{\circ}$ & 1.7 & 5.6 & $0.7^{\circ}$ & $1.4^{\circ}$ & 1.4 \\
\hline+ DIN and UV & - & $2.3^{\circ}$ & $2.1^{\circ}$ & $2.0^{\circ}$ & $0.5^{\circ}$ & $2.0^{\circ}$ & 2.1 & 2 \\
\hline
\end{tabular}

pool with little assimilable $\mathrm{N}$, a larger amount of DOM had to be turned over to fulfill the bacterial $\mathrm{N}$ demand. Low amounts of DIN $\left(\mathrm{NH}_{4}{ }^{+}\right.$and urea) were present in July, but apparently these $\mathrm{N}$ compounds were less attractive than DON to the bacteria. DIN may be especially important when labile $C$ sources like monosaccharides are available (Kirchman et al. 1990). The significant accumulation of DOC (up to $600 \mu \mathrm{M}$ ) observed in the southern part of the Gulf of Riga in July and August (Zweifel 1999) may also be related to the low lability of DON in the summer.

The comparable algal biomass along the Saulkrasti transect in May and July, despite the summer DIN deficiency, suggests that other $\mathrm{N}$ compounds were utilized by the phytoplankton in the summer. DON has usually not been considered a major $\mathrm{N}$ source to phytoplankton, but recent studies suggest that phytoplankton can exploit natural DON compounds as an alternative to DIN (Carlsson et al. 1995, 1998, Berg, Glibert \& Jørgensen unpubl. data). DON may be of special importance in the Gulf of Riga, where the phytoplankton community in the southern part of the gulf is dominated by cyanobacteria in the summer. Cyanobacteria have recently been found to possess a large potential for uptake of DON (Maestrini et al. 1997, 1999). Thus, bacterioplankton and phytoplankton probably competed for labile DON during summer along the Saulkrasti stations.

\section{Effect of $\mathrm{C}$ and $\mathrm{N}$ additions on bacterial growth capacity}

Amendment with $\mathrm{C}$ (glucose) or $\mathrm{N}\left(\mathrm{NH}_{4}{ }^{+}\right.$and $\mathrm{NO}_{3}{ }^{-}$) to cultures from the inner and outer stations indicated that bacteria in May, but not in July, were limited by $\mathrm{C}$ rather than N. Addition of $\mathrm{C}$ led to a 1.2- to 5.8-fold higher bacterial biomass at Köiguste and Saulkrasti, except for the unaffected inner Köiguste station in May (Table 3). In the Köiguste cultures, enrichment with DIN increased the bacterial biomass from 3.5- to 5.3-fold, but as for $\mathrm{C}$ no effect was found at the inner station in May. In the Saulkrasti cultures, addition of DIN only had an effect in July, when a doubling of the bacterial biomass was found. The lack of stimulation from addition of $N$ at the inner Köiguste station and the limited stimulation by both $\mathrm{C}$ and $\mathrm{N}$ in most of the Saulkrasti samples, despite the depleted $N$ conditions

Table 4. Effect of $12 \mathrm{~h}$ light treatment on concentrations of various nitrogen compounds in water from the Gulf of Riga. Only concentration changes statistically significant at a $5 \%$ level ( $t$-test) are included.,+- , nc: production, decrease or no changes in concentration, respectively. Sum of changes of $\mathrm{C}$ compounds (DCAA and DFAA) and $\mathrm{N}$ compounds (all shown substances) due to the light treatment is indicated

\begin{tabular}{|c|c|c|c|c|c|c|c|c|}
\hline \multirow[b]{3}{*}{ Dist. from shore $(\mathrm{km})$} & \multicolumn{4}{|c|}{ Köiguste } & \multicolumn{4}{|c|}{ Saulkrasti } \\
\hline & \multicolumn{2}{|c|}{ May 9} & \multicolumn{2}{|c|}{ July 25} & \multicolumn{2}{|c|}{ May 16} & \multicolumn{2}{|c|}{ July 31} \\
\hline & 0.2 & 13 & 0.2 & 13 & 0.1 & 5.3 & 0.1 & 5.3 \\
\hline DCAA & $+32 \%$ & $+12 \%$ & $+21 \%$ & nc & nc & $+59 \%$ & $+18 \%$ & $\mathrm{nc}$ \\
\hline DFAA & $-45 \%$ & $-31 \%$ & $+65 \%$ & $-29 \%$ & $-19 \%$ & $\mathrm{nC}$ & nc & nc \\
\hline $\mathrm{NH}_{4}{ }^{*}$ & $-64 \%$ & nc & nc & $-35 \%$ & $-82 \%$ & $-64 \%$ & nc & $-58 \%$ \\
\hline $\mathrm{NO}_{3}$ & nc & nc & nc & nc & $-21 \%$ & $-57 \%$ & nc & nc \\
\hline Urea & $+53 \%$ & $+30 \%$ & nc & $-20 \%$ & nc & $-27 \%$ & $\mathrm{nc}$ & $\mathrm{nc}$ \\
\hline Tot. C balance ( $\mu \mathrm{M} \mathrm{C})$ & 4.5 & 1.3 & 2.7 & -0.3 & -0.2 & 8.8 & 3 & 0 \\
\hline Tot. $N$ balance $(\mu \mathrm{M} N)$ & 0 & 1 & 1 & -1 & -14.1 & -12.5 & 1.1 & 2.5 \\
\hline
\end{tabular}


in the summer, may indicate that elements other than $\mathrm{C}$ and $\mathrm{N}$ controlled the bacterial growth. Phosphorus was added to all the $\mathrm{C}$ - and N-enriched cultures (N/P ratio of 4.1) and thus $P$ probably did not limit the growth. Maestrini et al. (1999) found that iron stimulated the algal growth in the gulf in summer, and since iron may also control bacterial growth (Tortell et al. 1996) this or other metals may have affected the low bacterial response to the $\mathrm{N}$ addition.

\section{Effect of light on $\mathrm{N}$ compounds and bacterial growth capacity}

Light exposure (mainly UV-A; 320 to $400 \mathrm{~nm}$ ) of water from the transects (before addition of bacterial inocula) had a variable effect on concentrations of the studied nitrogen compounds (Table 4). In about half of the samples no effects of light were found. When changes occurred, production of DCAA and a decline of $\mathrm{DFAA}_{1} \mathrm{NH}_{4}^{+}$and $\mathrm{NO}_{3}^{-}$typically occurred. while urea was either produced or removed. The smallest effect of light was measured in July at the Saulkrasti transect, when only DCAA $(0.1 \mathrm{~km})$ and $\mathrm{NH}_{4}{ }^{+}(5.3 \mathrm{~km})$ changed. The total effect of light exposure on the measured $\mathrm{C}$ and $\mathrm{N}$ compounds varied from -0.3 to $8.8 \mu \mathrm{MC}$ and -14 to $2.5 \mu \mathrm{M} \mathrm{N}$, respectively.

In 3 of the 4 Köiguste cultures, light pre-treatment in combination with $\mathrm{C}$ addition led to a higher bacterial biomass than when glucose alone was added (Table 3 ). This suggests that compounds produced by photolysis increased the bacterial glucose utilization. The stimulating substance(s) were apparently not among the studied DON and DIN compounds, as the total lightinduced $N$ formation (Table 4) was modest (or negative), relative to the ambient $N$ pools in the water. In the Saulkrasti cultures, the light treatment did not increase the previously found stimulation by glucose, but, somewhat unexpected, a diminished effect of glucose was measured after light exposure in 2 of the cultures.

The enrichment with DIN after light treatment also led to a reduced biomass in the Köiguste samples; in contrast, in the Saulkrasti cultures light increased the bacterial biomass up to 2-fold in May, but no effects were seen in July. The bacterial stimulation from addition of DIN at the 2 Saulkrasti stations in May was probably compensation for the light-induced decrease of $\mathrm{NH}_{4}{ }^{+}, \mathrm{NO}_{3}{ }^{-}$and urea (urea only declined at the $5.3 \mathrm{~km}$ station) (Table 4). In addition, the production of DCAA at the $5.3 \mathrm{~km}$. station may also have increased the bacterial production at that station.

Sunlight has previously been found to transform natural $C$ and $N$ compounds, including recalcitrant $D O C$, into substances that can be readily utilized by aquatic bacteria (Lindell et al. 1995, Wetzel et al. 1995, Bushaw et al. 1996, Jørgensen et al. 1998). The reduced bacterial growth in several of the cultures suggests, however, that light changed otherwise labile material into more recalcitrant or inhibitory compounds. Consistent with this, Tranvik \& Kokalj (1998) found that natural humic matter after light radiation reduced the bacterial uptake of algal DOM. The effect of sunlight on bacterial DOC and DON cycling is difficult to predict, and extrapolation from laboratory studies to natural systems should probably be performed with care. Further research in solar

Fig. 7. L and D enantiomers of glutamic acid and alanine in DCAA (A to D) along the Köiguste and Saulkrasti transects and (E) in the $30 \mathrm{~m}$ Saulkrasti depth profile in 1996. Means of triplicate samples shown. Error bars in (A)to (D) are $\pm 1 \mathrm{SD}$. (E) SDs were 3 to $7 \%$ (not shown) 
effects on natural DIN and DON is needed to evaluate the ecological consequences.

\section{Amino acid enantiomer ratios as indicators of substrate availability}

\author{
In situ L/D ratios of DCAA in transects and \\ depth profiles
}

The $L / D$ ratio of glutamic acid and alanine in the DCAA pool was determined in the Köiguste and Saulkrasti transects and in 2 depth profiles in May and July. In May, the L/D ratios decreased (Köiguste) or increased (Saulkrasti) with distance from shore, while the highest $L / D$ ratios in July occurred at the inner and outer stations (Köiguste), or the inner station (glutamic acidi Saulkrasti) (Fig. 7A to D). The increased L/D ratios indicate an input of organic matter with a high content of $\mathrm{L}$ amino acids, most likely from phytoplankton. The highest $L / D$ ratios did not, however, coincide with a maximum algal biomass (chl a or phaeopigments), which either occurred at the outer station (Köiguste) or the intermediary $1.4 \mathrm{~km}$ station (Saulkrasti). Rather, the L/D ratios reflect a previously high local phytoplankton growth, or input of allochthonous organic matter, e.g. from stations closer to shore in the transect.

In the depth profile, the $L / D$ ratio of glutamic acid and alanine at the outer Saulkrasti station in May was reduced from 8.3 to 3.7 (glu) and 6.2 to 3.0 (ala) between the surface and $30 \mathrm{~m}$ depth (Fig. 7E). In July, the L/D ratios varied between 5.2 and 6.1 (glu) and 3.4 and 4.4 (ala). An increase from the surface to 3-6 $\mathrm{m}$ depth was observed for both amino acids, but otherwise no depth-related trends were obvious. The declining $L / D$ ratio with depth in May suggests that new DOM was produced in the upper water column. The high primary production in the southern part of the gulf in spring (Baloda 1999) was probably the source of $\mathrm{L}$ amino acids. At the bottom bacterial degradation had reduced the $\mathrm{L}$ amino acids during the winter, and in May, shortly after the ice cover broke, new DOM had not yet been transported into the bottom strata, resulting in low L/D ratios.

In July, the $L / D$ ratio of glutamic acid increased between 3 and $6 \mathrm{~m}$ and at the bottom. In July the previous year (1995), a high algal density occurred in the subsurface layer in the southern part of the gulf (Tamminen \& Seppälä 1999). If the phytoplankton had a similar distribution in 1996, the higher abundance of $L$ amino acids between 3 and $6 \mathrm{~m}$ and at $30 \mathrm{~m}$ might have been caused by release from planktonic or settled algal cells in the water column and at the bottom, respectively.

\section{L/D ratios relative to bacterial growth potential}

Analysis of DCAA in the carrying capacity studies demonstrated a reduction of the $L / D$ ratio over time in 10 of the 14 cultures, as exemplified for glutamic acid in Fig. 8A. In the Köiguste samples, the ratio was reduced by 20 to $40 \%$, except at the outer $13 \mathrm{~km}$ station in May, where no changes occurred. In the Saulkrasti samples, a 20 to $50 \%$ reduction was measured in May, but in July a minor reduction only occurred at the outer $5.3 \mathrm{~km}$ station.
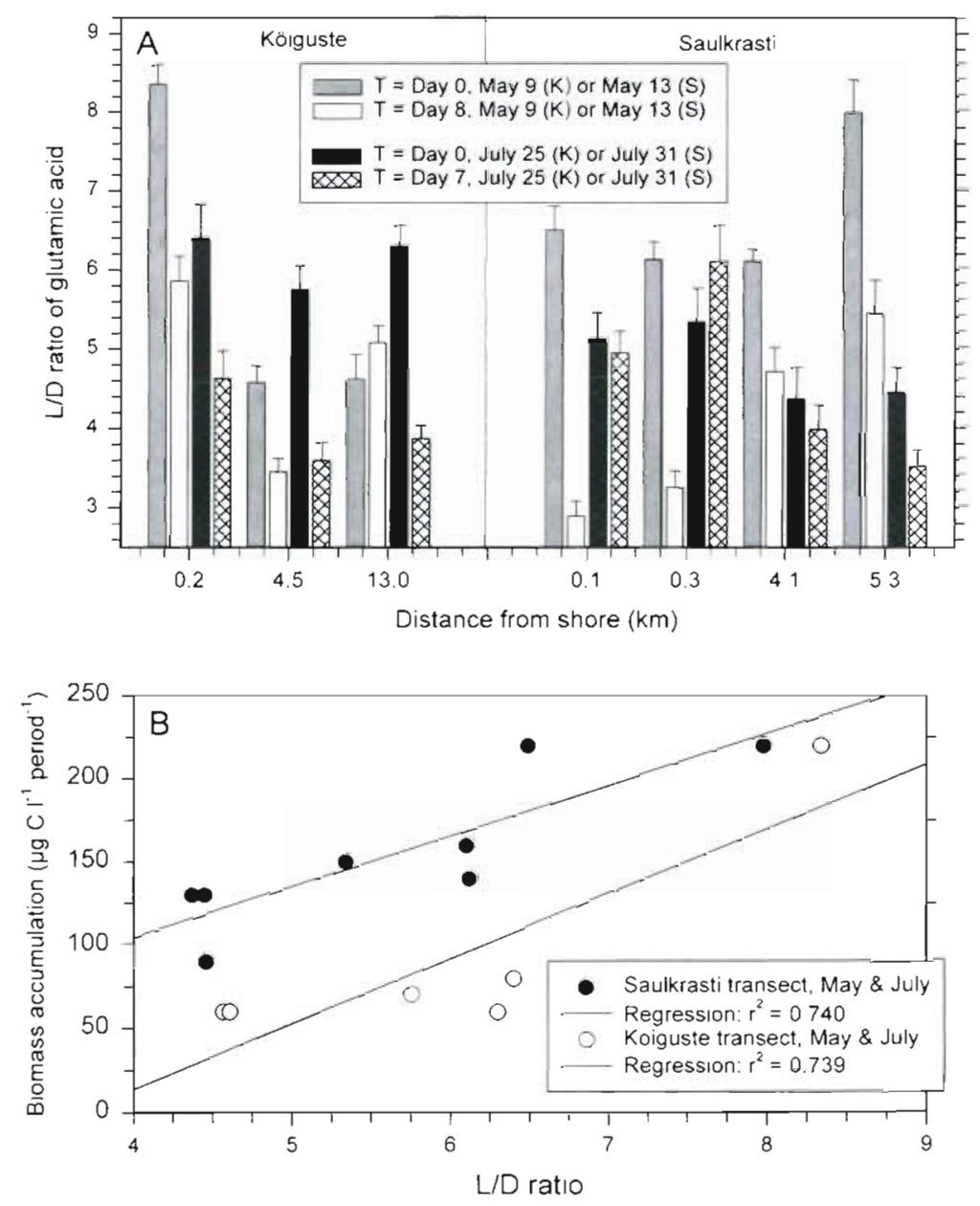

Fig. 8. (A) Changes in L/D ratio of hydrolysable glutamic acid in DCAA from the Köiguste (K) and Saulkrasti (S) carrying capacity studies in 1996. Samples were incubated for $8 \mathrm{~d}$ (May) or $7 \mathrm{~d}$ (July). (B) Linear regressions of the L/D ratio of glutamic acid (Fig. 8A) vs biomass accumulation (Fig. 6) in the 2 transects 
The similar variations in bacterial biomass accumulation and $L / D$ ratios of glutamic acid and alanine in water along the transects (Figs. 6 \& 7) suggest that $L$ (protein) amino acids were the preferred bacterial amino acid enantiomer during degradation of DCAA. A regression of the biomass production over the 7 or $8 \mathrm{~d}$ of incubation (Fig, 6) and L/D ratio of glutamic acid at the start of the incubations (Fig. 8A) demonstrated a linear relationship with a correlation coefficient $\left(\mathrm{r}^{2}\right)$ of 0.74 (Fig. 8B). The coincidence of a large biomass production and a high $L / D$ ratio shows that a large pool of labile DOM was present at the high L/D ratios. Thus, our data indicate that the DCAA enantiomer ratio can be used as an indicator of DOM lability.

The minimum L/D ratio of glutamic acid of about 3.5 in the carrying capacity studies and in the depth profile (alanine had a minimum ratio of 3 in the depth profile) is probably the lower threshold limit of the $L / D$ ratio of labile DOM. This threshold value may represent a balance between (1) the general bioavailability of $L$ and $D$ enantiomers, e.g. the lability of amino acids combined with other DOM molecules; (2) the production of D amino acids (mainly from peptidoglycan in bacterial cell walls); and (3) the bacterial capacity for utilization of $\mathrm{D}$ amino acids, which may be lower than for L amino acids (Hopkins et al. 1994).

Application of amino acid enantiomers for characterization of DOM has not been widely used, and published values are somewhat conflicting. D enantiomers in the sea have been found to make up from trace amounts (Sigleo et al. 1983) to about 10\% (Lee \& Bada 1977), while McCarthy et al. (1998) report that about $20 \%$ of 9 amino acids in high molecular weight (HMW) DOM from ocean depths of 2 to $4000 \mathrm{~m}$ were D enantiomers. McCarthy et al. (1998) did not find a relation between $L / D$ ratio and water depth as observed in the Gulf of Riga in spring. Possibly the labile DOM pool was not included in the analysed HMW fraction of DOM. Further studies are required to test the application of amino acid enantiomers as indicators of DOM lability.

\section{CONCLUSIONS}

The present results indicate that there is active microbial cycling of DON in the Gulf of Riga, and that DON is an essential element in the regulation of the mineralization of DOM. The large input of DON from the Daugava River had a major impact on the microbial activity in the southern part of the gulf. Seasonal changes of the DON lability appeared to influence the degradation of DOC in summer, as indicated by an estimated $\mathrm{C} / \mathrm{N}$ ratio of labile DOM of 43 in July, as compared to 4 in May. The estimated labile DON frac- tion of about $13 \%$ corresponds to a DON residence time of $7.5 \mathrm{yr}$. This is close to the residence time of 5.7 yr estimated for the total $N$ pool in the Gulf of Riga (HELCOM 1996). However, considering the residence time of the gulf water body of about $3 \mathrm{yr}$, a portion of the DON pool is probably not degraded in the gulf, but exported to the Baltic Sea. The present work is based on relatively few samplings and therefore may not represent interannual or even typical annual variations, but we hope that the results will stimulate further research in nitrogen dynamics in the Gulf of Riga.

Acknowledgements. We wish to thank E. Boikova and colleagues from the Department of Marine Ecology, Institute of Aquatic Ecology, University of Latvia, and D. Conley and F. Mohlenberg, National Environmental Research Institute, Denmark, for assistance during collection and incubation of samples in the field. We acknowledge the skilful assistance by $H$. Olufsson, C. Wolsted and R. E. Jensen in analyses of bacterial growth parameters and different nitrogen compounds. We also acknowledge critical and constructive comments on the manuscript by P. M. Glibert, Horn Point Environmental Laboratory, University of Maryland, USA. This study was supported by the Nordic Council of Ministers as a part of the Nordic Environmental Research Programme in the Gulf of Riga, grant no. 802-670-96Fh, and the Danish Natural Science Research Council, grant no. 9601731

\section{LITERATURE CITED}

Azam Fr Fenchel T, Field JG, Gray JS, Meyer-Reil LA, Thingstad F (1983) The ecological role of water column microbes in the sea. Mar Ecol Prog Ser 10:257-273

Babichenko S, Kaitala S, Leeben A, Poryvkina L, Seppälä J (1999) Phytoplankton pigments and dissolved organic matter distribution in the Gulf of Riga. J Mar Syst 23:69-82

Baloda M (1999) The use of phytoplankton for assessment of environmental quality of the Gulf of Riga, PhD thesis, University of Latvia

Bauerfeind S (1985) Degradation of phytoplankton detritus by bacteria: estimation of bacterial consumption and respiration in an oxygen chamber. Mar Ecol Prog Ser 21:27-36

Berzinsk V (1995\} Hydrological regime. In: Ojaver E (ed) Ecosystem of the Gulf of Riga between 1920 and 1990 Estonian Academy Publishers, Tallin, p 7-31

Billen G, Joiris C. Wijnant J (1980) Concentration and microbiological utilization of small organic molecules in the Scheldt Estuary, the Belgian coastal zone of the North Sea and the English Channel. Estuar Coast Mar Sci 11: 279-294

Bushaw KL, Zepp RG, Tarr MA, Schuiz-Jander D, Bourbonniere RA, Hodson RE, Miller WL, Bronk DA, Moran MA (1996) Photochemical release of biologically available nitrogen from dissolved organic matter. Nature 381. $404-407$

Capone DG, Ferrier MD, Carpenter EJ (1994) Amino acid cycling in colonies of the planktonic marine cyanobacterium Trichodesmium thiebautii. Appl Environ Microbiol 60:3989-3995

Carlsson P, Graneli E, Tester P, Boni L (1995) Influences of riverine humic substances on bacteria, protozoa, phytoplankton, and copepods in a coastal plankton community. Mar Ecol Prog Ser 127:213-221 
Carlsson P, Edling $\mathrm{H}$, Béchemin C (1998) Interactions between a marine dinoflagellate (Alexandrium catenella) and a bacterial community utilizing riverine humic substances. Aquat Microb Ecol 16:65-80

Cho BC, Park MG, Shim JH, Azam F (1996) Significance of bacteria in urea dynamics in coastal surface waters. Mar Ecol Prog Ser 142:19-26

Coffin RB (1989) Bacterial uptake of dissolved free and combined amino acids in estuarine waters. Limnol Oceanogr $34: 531-542$

Flynn KJ, Berry LS (1999) The loss of organic nitrogen during marine primary production may be significantly overestimated when using ${ }^{15} \mathrm{~N}$ substrates. Proc R Soc Lond B 266 : $641-647$

Fry JC (1988) Determination of biomass. In: Austin B (ed) Methods in aquatic bacteriology. Wiley \& Sons, London, p $27-72$

Fuhrman JA (1990) Dissolved free amino acid cycling in an estuarine outflow plume. Mar Ecol Prog Ser 66:197-203

Granéli E, Granéli W, Rydberg L (1986) Nutrient limitation at the ecosystem and the phytoplankton community level in the Laholm Bay, south-east Kattegat. Ophelia 26:181-194

Granéli E, Wallström K, Larsson U, Granéli W, Elmgren R (1990) Nutrient limitation of primary production in the Baltic Sea area. Ambio 19:142-151

Hammer KD, Brockmann UH, Kattner G (1981) Release of dissolved free amino acids during a bloom of Thalassiosira rotula. Kiel Meeresforsch Sonderh 5:101-109

HELCOM (Helsinki Commission) (1996) Third periodic assessment of the state of marine environment of the Baltic Sea, 1889-1993; Background document. Balt Sea Environ Proc $64 \mathrm{~B}$

Hellebust JA (1965) Excretion of some organic compounds by marine phytoplankton. Limnol Oceanogr 10:192-206

Hoch MP, Kirchman DL (1995) Ammonium uptake by heterotrophic bacteria in the Delaware estuary and adjacent coastal waters. Limnol Oceanogr 40:886-897

Hopkins DW, Isabella BL, Scott SE (1994) Relationship between microbial biomass and substrate induced respiration in soils amended with D- and L-isomers of amino acids. Soil Biol Biochem 26:1623-1627

Ittekkot V (1982) Variations of dissolved organic matter during a plankton bloom: qualitative aspects, based on sugar and amino acid analysis. Mar Chem 11:143-158

Jørgensen NOG, Jensen RE (1997) Determination of dissolved combined amino acids using microwave-assisted hydrolysis and HPLC precolumn derivatization for labelling of primary and secondary amines. Mar Chem 57: $287-297$

Jørgensen NOG, Kroer N, Coffin RC, Yang XH, Lee C (1993) Dissolved free amino acids, combined amino acids, and DNA as sources of carbon and nitrogen to marine bacteria. Mar Ecol Prog Ser 98:135-148

Jørgensen NOG, Kroer N, Coffin RB (1994) Utilization of dissolved nitrogen by heterotrophic bacterioplankton. Effect of substrate C/N ratio. Appl Environ Microbiol 60: $4124-4133$

Jørgensen NOG, Tranvik L, Lindell M, Granéli W, Edging $H$ (1998) Effects of natural sunlight on bacterial utilization of specific carbon and nitrogen compounds in freshwater. FEMS Microbiol Ecol 25:217-227

Keil NG, Kirchman DL (1993) Dissolved combined amino acids: chemical form and utilization by marine bacteria. Limnol Oceanogr 38:1256-1270

Kirchman DL, Keil NG, Wheeler PA (1990) Carbon limitation of ammonium uptake by heterotrophic bacteria in the subarctic Pacific. Limnol Oceanogr 35:1258-1266
Kristiansen S (1983) Urea as an important source of nitrogen on the Oslofjord. Mar Biol 74:17-24

Kroer N, Jorgensen NOG, Coffin RB (1994) Utilization of dissolved nitrogen by heterotrophic bacterioplankton. A comparison of three Ecosystems. Appl Environ Microbiol $60: 4116-4123$

Kukk H (1993) Floristic composition of the phytobenthos and its long-term changes in the Gulf of Riga, the Baltic Sea. Proc Estonian Acad Sci Ecol 3:85-91

Lee C, Bada LJ (1977) Dissolved amino acids in the equatorial Pacific, the Sargasso Sea, and Biscayne Bay. Limnol Oceanogr 22:502-510

Lindell MJ, Granéli WL, Tranvik. LJ (1995) Enhanced bacterial growth in response to photochemical transformation of dissolved organic matter. Limnol Oceanogr 40:195-199

Lindroth P, Mopper K (1979) High performance liquid chromatographic determinations of subpicomole amounts of amino acids by precolumn fluorescence derivatization with o-phthaldialdehyde. Anal Chem 51:1667-1674

Maestrini SY, Balode M, Béchemin C, Purina I, Vérité C (1997) Nutrients limiting the Algal Growth Potential (AGP) in the Gulf of Riga, eastern Baltic Sea, in spring and early summer 1996. La Mer 35:49-68

Maestrini SY, Baloda M, Béchemin C, Purina l (1999) Nitrogenous organic substances as potential nitrogen sources, for summer phytoplankton in the Gulf of Riga, eastern Baltic Sea. Plankton Biol Ecol (Japan) 46:8-17

McCarthy MD, Hedges JI, Benner R (1998) Major bacterial contribution to marine dissolved organic nitrogen. Science 282:231-234

Mopper K, Furton KG (1991) Extraction and analysis of polysaccharides, chiral amino acids, and SFE-extractable lipids from marine POM. Geophys Monogr 63:151-161

Nimura N, Kinoshita T (1986) o-phthalaldehyde-N-acetyl-Lcysteine as a chiral derivatization agent for liquid chromatographic optical resolution of amino acids enantiomers and its application to conventional amino acid analysis. J Chromatogr 352:169-177

Porter KG, Feig YS (1980) The use of DAPI for identifying and counting aquatic microflora. Limnol Oceanogr 25:943-948

Price NM, Harrison PJ (1987) Comparison of methods for the analysis of dissolved urea in seawater. Mar Biol 94: $307-317$

Seitzinger SP, Sanders RW (1997) Contribution of dissolved organic nitrogen from rivers to estuarine eutrophication. Mar Ecol Prog Ser 158:1-12

Shiah FK, Ducklow HW (1994) Temperature and substrate regulation of bacterial abundance, production and specific growth rate in Chesapeake Bay, USA. Mar Ecol Prog Ser 103:297-308

Sigleo A.C, Hare PE, Helz GR (1983) The amino acid composition of estuarine colloidal material. Estuar Coast Shelf Sci 17:87-96

Stålnacke P (1996) Nutrients loads to the Baltic Sea. Linköping Studies in Arts and Science No. 146. PhD thesis, Linköping University, Linköping

Stipa T, Tamminen I. Sappälä J (1999) On the creation and maintenance of stratification in the Gulf of Riga. J Mar Syst 23:27-49

Tamminen $\Upsilon$, Seppälä J (1999) Nutrients pools, transformations, ratios, and limitation in the Gulf of Riga, the Baltic Sea, during four successional stages. J Mar Syst 23:83-106

Thurman EM (1985) Organic geochemistry of natural waters. Nijhoff/Junk Publishers, Boston

Tortell PD, Maldonado MT, Price NM (1996) The role of heterotrophic bacteria in iron-limited ocean ecosystems. Nature 383:330-332 
Tranvik LJ (1998) Rapid fluorometric assay of bacterial density in lake water and seawater. Limnol Oceanogr 42: $1629-1634$

Tranvik L, Kokalj S (1998) Decreased biodegradability of algal DOC due to interactive effects of UV radiation and humic matter. Aquat Microb Ecol 14:301-307

Wetzel RG, Hatcher PG. Bianchi TS (1995) Natural photolysis by ultraviolet irradiance of recalcitrant dissolved organic

Editorial responsibility: Otto Kinne (Editor),

Oldendorf/Luhe, Germany matter to simple substrates for rapid bacterial metabolism Limnol Oceanogr 40:1369-1380

Yurkovskis A, Wulff F, Rahm L, Andruzaitis A, RondrigezMedina M (1993) A nutrient budget of the Gulf of Riga Baltic Sea. Estuar Coast Shelf Sci 37:113-127

Zweifel UL (1999) Factors controlling bacterial growth and accumulation of labile dissolved organic carbon in the Gulf of Riga. Estuar Coast Shelf Sci 48:357-370

Submitted: January 25, 1999; Accepted: August 17, 1999

Proofs received from author(s): December 16, 1999 